\title{
1981 年度秋季学術大会記事・発表要旨
}

1981 年度秋季学術大会は, 10 月 17 日・18 日・19日の 3 日間にわたって, 岩手大学人文社会科学部を主会場として 開催された。

10 月 17 日・18 日の 2 日間は研究発表があり活発な討議 がかわされた。10月17日の夜には盛岡城跡には活ど近い 北ホテルに拈いて懇親会が行なわれ, 約 50 名の参加者があ り盛会であった。

10 月 19 日には「地方都市『盛岡』の変貌」をテーマとし
て，盛岡市を中心とした巡検が行なわれたが，その詳細に ついては別の報告にゆずりたい。

今回の大会は岩手県ならびに秋田県の一地域の総合的研 究が発表されるなど, 東北地理学会の特徵がよく表われた 大会であったといえる。大会の直接の運営にあたられた岩 手大学教育学部ならびに人文社会科学部の方々には深く感 謝申し上げたい。

（文責 阿部 隆）

\section{発表 要旨}

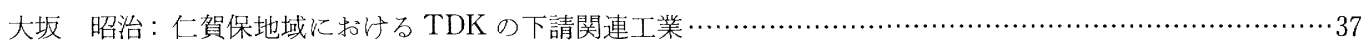

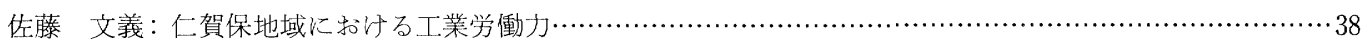

益子 清孝：仁賀保地域の文化

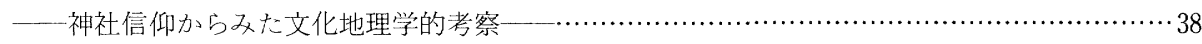

阿部 和夫：北上山地北部の開田とその特色

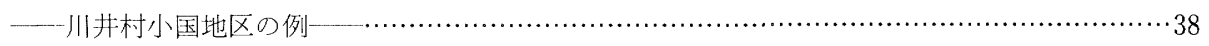

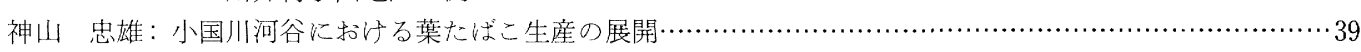

田口 淳一：人口構造からみた山村の変貌

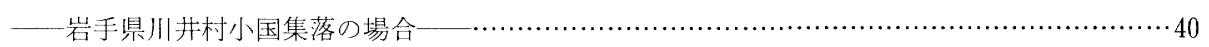

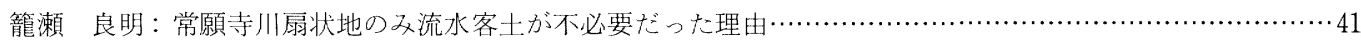

阿子島 功：吉備山地の準平原問題 (3)

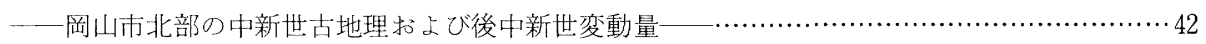

千葉 德爾: 間引きについて 一第 2 報——

重見 之雄：塩田の工場用地への転用について

一山口県下松塩田の場合

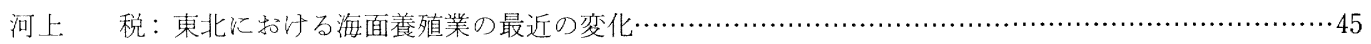

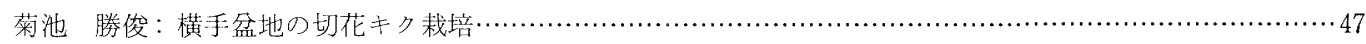

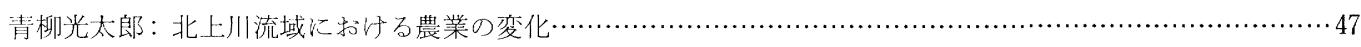

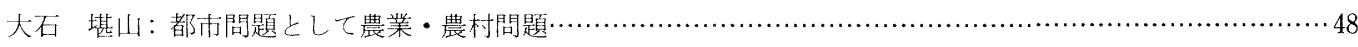

菅原啓・山中 三男：外山川上流地域の段丘・湿原堆積物の堆積環境に関する考察……………………4

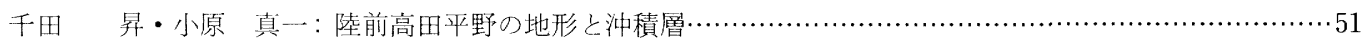

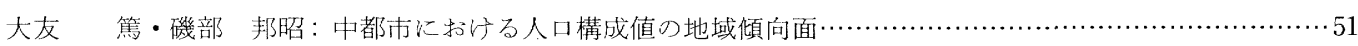

水見山幸夫：メッシュの移動によるパターンの変動について

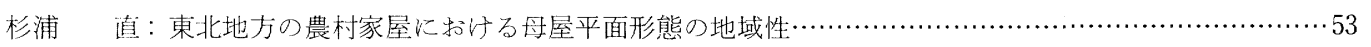

梅林筒・阿部隆：旧城下町盛岡の市街地形態の変化と都心地区の形成…………………………5

菅沼 健：房総半島南部及び三浦半島南部の完新世海成段丘と地震性地殼変動…………………………5

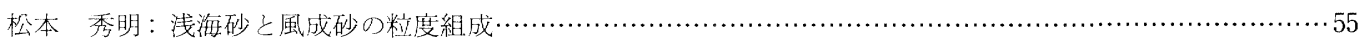

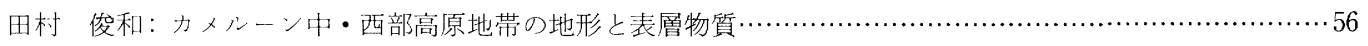

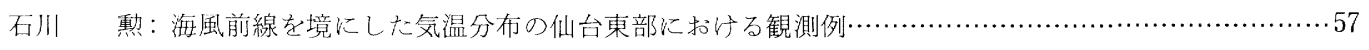

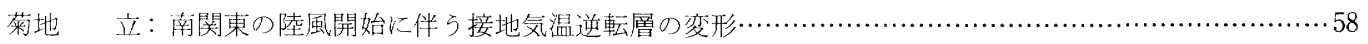




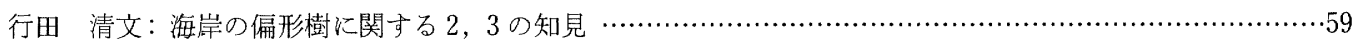

牧田 肇：弘前市から見た岩木山の雲分布……………………………………………………………6

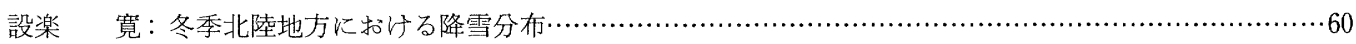

\section{仁賀保地域に括活るTDK の関連下請工業}

大 坂 昭 治

秋田県由利郡仁賀保地域とその周辺地域に抢ける工業の 特色を, 東京電気化学工業株式会社 (以下 TDK といら) 秋 田地区工場群の設立とそれに伴う関連下請工業の発達過程 と実態を通して考察する。TDK 秋田地区工場総務部・町 役場・地元商工会からの資料と, 関連下請会社へのアン ケート調查掞よび聴き取り調查による資料を基に進めた。

結果

(1) 本荘由利地域に括汁る電気機械器具製造業の地位は きわめて高く, 事業所数で全県比 $38.7 \%$, 従業者数で同 $47.4 \%$, 製造品出荷額で同 $58.3 \%$, 粗付加価值額で同 $62.4 \%$

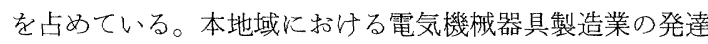
は, TDK 抢よびその関連下請工業に依存する傾向が強い。

(2) 関連下請工業地域の核心をなす賀保町の第 2 次産 業人口率は, 昭和 54 年現在 $43.3 \%$ で, こ机は秋田県内の市 部・同規模の町部に比していずれよりる高い割合である。 玉た, 同町の製造業就業人口は, 約 3,000 人で, 全就業人 口の $34.4 \%$ を占めている。

(3) 仁賀保町の電気機械器具製造業についてみると, 事 業所数で全体の $47.7 \%$, 従業者数で $83.3 \%$, 現金給与総額 で $87.9 \%$, 出荷額で $90 \%$ を占めていることから, 弱電関係 の製造工業が地域産業の中枢をなしていると考光られる。

(4) TDKの関連下請工業は，仁賀保地域を中心に招こ り, 次第にその周辺地域一之波及していった。工場分布は, 仁賀保町だけで全体の $21 \%$ ，金浦町・象潟町・本荘市の 3 市町を含めると全体の $52 \%$ となって拈り, また隣県山形県 （遊佐町・鶴岡市・酒田市・余目町）が $17 \%$ となってい る。業種は, 大半がフェライトやセラミックコンデンサな どの部品加工であるが, 関連工業としての段ボール・発泡 スチロール・金䌊などの製作や印刷業など多種とわたって いる。

(5) 関連下請会社の設立年代は, 昭和 30 年代と 40 年代 がほとんどで, こ礼は, テレビ受像機・トランジスタラジ オなどの普及に伴って, TDK 秋田地区工場群の生産実績 が向上した時期と一致している。TDK 出資 100\%によっ て設立したサテライト会社 (子会社) 㹥もちろんであるが,
関連会社の設立者は, 一次下請会社で約 20 社が TDK 出身 者によって創設された。このことから，関連会社設立の経 緯には, TDK との人的関係の強さを反映しているといえ る。

(6) TDK が 100\% 出資するサテライト会社を除くと, 関連下請会社の資本金は，半数近くが 1,000 万円以下の小 規模会社である。年間売上高 10 億円以上の会社は $44 \%$ を 占め, その多くはサテライト会社と比較的規模の大きい下 請会社である。TDK への納品率は, 関連会社の約 4 分の 3 にあたる会社が，100\%ないしは $90 \%$ 台の納品率を示し， TDK との直結型が多い。

(7) TDK 秋田地区工場とその関連下請工場をらくくた 従業者数は，扮扮よそ 13,000 人に達し，内サテライト会 社・一次下請・二次下請内職従事者が $80 \%$ を占めている。 関連従業者の男女比は, 注涪 $1: 3$ で, $1: 5$ 以上の会社が 48\%を占めていることから, 関連下請工場の労㗢構造は女 子労働主導型とい光よう, 内職者は全従業者の約 3 分の 1 を占め, これは臨時工員・パート工員の多いことと合せて 考光机ば, きわめて重要な意味をるつ。

(8) 関連下請工場従業者の年令別構成は, 20 才代が $37.6 \%, 30$ 才代が $35 \%$ で青壮年層に集中している。貨金別 構成についてみると, 年間給与額 1 人 $100 \sim 150$ 万円の会社 が全体の $60 \%$ 近くを占めている。京た, 月額 1 人当り 10 万 円以下の従業者が 4 分の 3 を占めていることから考えて, その賃金水準はさわめて低いといえよう。これは，臨時工 員やパート工員の占好比率が高いことも起因しているも のと考光られる。

な特, 従業者規模の大きい会社活ど 1 人当りの給与額が 大きく, 年間稼動日数の多い会社注ど 1 人当り給与額が小 さい。後者については，小規模な会社济ぞ週休 2 日制なぞ の労働条件が整わず, 稼動日数が多い割汇貢金が低いこと を示しているといえよう。

下請工業は, 手作業にたよる労働集約型生産であるため, その収益の増減は, 従業者数と賃金水準に大きく左右され るものと考光られる。 


\section{仁賀保地域に打ける工業労働力}

本研究は共同研究「TDK の進出に伴ら地域社会の変容_ の一部である。本報告では, 仁賀保地域とその周辺地域に

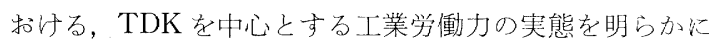
することを目的とした。調査は, 関係官宁の人口・工業統 計, 各工場の從業者名簿と現地での㯖き取りによった。

結 果

1. 本地域の製造業従事者は, TDK とその関連・下請 工場が設立された, 昭和 30 年代初期・同 43 年・同 53 年な どと増加をみている。

2. TDKとその関連・下請工場の従業者法，賀保地 域の製造業従事者の $60.8 \%$ を占めている。

3. 仁賀保地域の TDK 関係の大規模工場では男子従業
者の比率が高く, 小規模工場では女子従業者の比率が高い。

4. TDK 関係の大規模工場では通勤圈が広く，小規模 工場では狭い。この傾向纸仁賀保周辺の場合でも顕著であ る。

5. TDK関係の大規模工場では, 新規学卒者の就職率が 高く, 秋田大学鉱山学部出身者が多いこと必特色である。

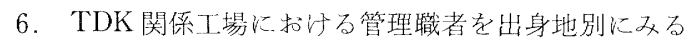
と，仁賀保地域が $31 \%$ ，県外が $35 \%$ である。本た，仁賀保 地域出身の管理職者は大学卒よりも高校卒の方が多い。

7. 農家出身の従業者も多いが, TDK 関係の大規模工 場で江零細経営出身者が多く, 小規模工場で泆大・中規模 経営出身者が多い。

\section{仁賀保地域の文化}

——神社信仰から反大文化地理学的考察——

本報告はTDKの進出にともなら地域社会の変容と題す る仁賀保地域の総合研究の一部であり, 神社信仰の民俗的 態様をと打して亿賀保地域の宗教的体系の地域的展開を明 らかとすることを目的としている。調查には, 明治 13 年秋 田県户籍係事務簿 (社寺の部) 資料, 大正 2 年 (省令 6 号) 神社明細帳，秋田県神社庁資料，その活かの文献，文書を 用いた活か，現地聞き取り調査によっだ。

対象地域は仁賀保 3 町（仁賀保町，金浦町，象潟町の旧 八郷 34 力町村）である。

結果として

1. 鳥海山と日本海がもたらした民俗的態様が，地域の 精神史, ことに地域信仰の要素となっている。賀保地域 は鳥海天台系修験を中心とする鳥海山の信仰と海上信仰神 に対する信仰が基盤となっている。
2. 仁賀保地域の歴史的特異性，すなわち由利十二頭の 抗争, 小藩分裂による仁賀保連合の形成と矢島地方々の確 執は中央の山岳信仰の波及に之もない鳥海山北麓を二分 し，仁賀保地域を信仰的にも統合してきた。

3. 立賀保地域の信仰的体系は日本海沿岸飞南北展開 し，民俗的諸要素，生活関係圈に反映されている。その領 域は北は本荘市芋川から南は山形県庄内地方に及几でい る。

4. 神社祭礼圈は一般的には社格の高い神社の祭祀圈々 社格の低い神社の祭祀圏との間に重合間係が久られるが， 当該地域では無格社であった仁賀保・斎藤神社の崇敬者祭 祀圈之鄉・村社祭祀圈との重合関係となる特異な形態と なっている。今日に执いても, 信仰的な伝統が維持されて いる。

\section{北上山地北部の開田とその特色}

一一井村小国地区の例—

阿部和夫

川井村小国は北上山地北部位置する。戦前に打计る小 国の特色は, 農業収入と山林収入によってなりたつ山村で あったことである。
明治末期から昭和初期の農用地は, 水田が 20 町内外, 畑 が 500 700 町, 山林が 6,000 町余で, 畑作物は自給用の 稗・麦・大豆がとびぬねて多い。これは北上山地に広くみ 
られる自給中心の畑作農業の典型をなすものである。

大正初期の土地利用は, 傾斜の计わしい山地が山林原野, 山腹の緩斜面と川ぞいの狭い平地が畑，沖積地のやや広い ところが水田となっている。

水田が明治末期から戦前にいたるまで 20 町内外にとど まっているのは, 平坦地が少ないといら地形的条件もさる ことながら，より根本的には低温・冷水・日照不足に起因 する生産力の低さと不安定によるものである。

昭和 30 年代の土地利用は, 20 年代末から始められた小 国・江繫土地改良事業の成果を反映して，水田がやや増加 している。この事業恃，積寒事業にくりこまれた幹線水路 事業を発端にとりあげられたものである。

40 年代の土地利用で特徵的なこと法，小国川ととの支流 川ぞいに水田が増加していることである。この時期の開田 は，共同施行によるものの汪か，開田請負業者や個人的な 労力によるものがあり，その規模はいずれも零細である。

100 ha をこえる水田の増加は, 経営的には自給主食の増 産をはかる農家の増大によるものであり，技術的には耐寒 品種の研究や保温折蜟苗代に代表される米作技術の向上に よるものである。そして経済的には，生産力の向上によっ て農家の事業費の負担力が向上したことを反映するもので
ある。

戦後の水田の増加が果した役割は，自給主食を畑で生産 する伝統的な生産形態を変革し，畑の自由な利用を可能に したことである。雑穀面積の減少と工芸作物並びに飼料作 物の増加は，その端的なあらわれである。とはいえ，その 面積はひところの畑面積にくらべて決して多いものでは ない。この第一の要因は，導入された主作物が専売局の制 約をら汁る葉たばこであったことと関連する。そして第二 には，畑経営が山あいの封鎖的な社会条件のもと，個別資 本や個別経営を中心とせざるをえないため，経営の適正規 模を上回る部分が粗放的な利用とならざるをえなかったこ とによるものである。

この点は, 元木 (1977) の, 米生産力の向上が自給食糧 の安定的な確保の段階をこえて, より積極的な米の商品化 を指向してきたとする，県北伊保内の報告と対照的である。

農業の経営形態は, 伝統的な「自給的畑作十農外労働 (山 林等)」から「自給的米作 + 商業的畑作」と「自給的米作 + 自給的畑作十農外労働」の二つに分化しているにすぎない。 これは米生産力の向上を契機として農業構造が大きく変質 してきたとはい立，自然条件その他の制約からいまだ山村 的な性格から好出していないことによるものである。

\section{小国川河谷に打注葉たばこ生産の展開}

神山忠 雄

本報告は, 昭和 36 年から葉たばこを導入した岩手県川井 村小国川河谷の山村が，高度経済にどのような事情のもと で葉たばこ生産を展開したかを明らかにしたものである。

小国川河谷は農耕地にそしく，葉たばこ栽培は狭小な耕 地か山麓緩斜面を利用して行なわれている。位置的には宮 古，釜石，盛岡など県内主要都市から隔離されてきた閉鎖 的状況にめった。

たばこ耕作組合宮古取り扱い所管内（8市町村を含导） で，川井村小国地区の葉たばこ栽培面積は，導入年の昭和 36 年に管内の $10.1 \%$ (883a) であったが，昭和 55 年には $25.5 \%(5,566 \mathrm{a})$ とその割合を増して, 人員ひとりあたりの 平均経営規模も 3.9 倍に拡大した。 55 年には，小国地区の 農家の 45\% (123 戸) で栽培されている。

葉たばこ導入前の畑地利用は，麦類，豆類，雑穀類を主 にしていたが，戦後から昭和 40 年代にかけて開田がなさ れ，米による主食の自給化が進むにつれて葉たばこに置き 換えられてきた。小国地区は前々から山林収入に依存して きたこともあって中高齢者の人口流出は少ない。今でも下 刚，補植などの造林関係促事し，これが兼業農家の多く を占める。

葉たばこ栽培農家は，小国地区全農家に比べて第一種兼
業農家率が高く，第二種兼業農家率は低くなっている。こ のことは葉たばこ生産が農家にとって大きな収入源となっ ていることを示すものであろう。葉たばこ以外にほほんど 商品作物をもたず，従って農作物の組み合わせは，自給用 水稲と葉たばこ，自給用水稲と自給用畑作物といら単純な 組み合わせが普通である。

経済規模は, 40～50 a の葉たばこと 40～60 a の水田，そ して販売と堆肥獲得のために肉牛が $1 \sim 2$ 頭飼育されてい る程度である。労働力は家族 2 3 人であるが, 農家によ。 ては葉たばこの植付, 収獲の繁忙期に雇用労働力に依存す るところもある。葉たばこは稲作との労働力の競合が弱い ので，機械力を導入しにくい事情もあるが，労働力に応じ た経営規模であれば農家にとって興味ある作物である。

葉たばこは品質の良し悪しが直接収納代金に響いてく る。順調に成育させる条件のひとつに仮植時期 (4 月初旬) をずらさないことがある。そのために親床 (3月中旬播種) は, 共同施設で作られて経費の節減とともに仮植時期を守 る結果ともなっている。一方，收獲後の乾燥はさらに注意 を要する。乾燥を良好にするために小国地区では，専売公 社の補助事業である火力を用いた「規格乾燥室」の導入に ついて他地区より積極的であるという。 
以上，高度経済成長期にめって，小国川河谷で葉たばこ 生産が持続，拉大されてきた要因を整理すれば次のように なる。

ひとつに，兼業として造林関係に従事することが多く, そのために中高齢者の労働力の流出が抑えられ, これが葉 たばこ生産に向计られたこと。つぎに, 他に有力な商品作
物をもたない地域にあっては，専売制に裏打ちされた葉た ばこへの傾斜を強めざるを得なかったこと。そして，品質 の向上のために，間接的には親床に打ける施設の共同化， 直接的に恃補助事業である「規格乾燥室」の積極的受け入 れという内部努力があったことなどである。

\section{人口構造からみた山村の実態}

岩手県川井村小国集落の場合一

田口淳一

川井村は北上山地中部に位置し, 面積は $563 \mathrm{~km}^{2}$, その $94 \%$ が林野で占められている。人口は 5,603 人（昭 55 ）で 慢性的減少を続け，人口密度はわずか 10.0 人 $/ \mathrm{km}^{2}$ と岩手 県最低位にある。西に接する盛岡市之東の広域生活圈に属 寸る宮古市とは，国鉄山田線，国道 106 号線で結ばれてい る。昭和 34 年 10,617 人を示した人口住半減し, 県内では 湯田町に次ぐ減少地域になっている。

しかし，この急激な人口流出は，地域経済あるいは村の 将来に大きな危機感と動摇を与えはしたが，村落崩壊を含 めた決定的打撃は幸いにも回避したかにみえる。何故なら， 昭和 40 年代は, 依然として生産年齢層が存在していたこ と，家制度の存続による一定のUターン者があったこと， 過踈法による対策として生活環境関連諸施設の整備, 交通 通信体系整備事業などの振興施策が補完的役割を果たした からである。さしろ，人口流出にともなら本格的困難期は これから具現化されるものと考光る。

ここでは, 川井村のなかでも, 最も農家世带率の高い小 国集落を事例に，山村の実態を考察した。

そのう法として，住民基本台帳で人口構造を把握，その 内容を吟味するため，住民異動届（昭 40～昭 55)，世界農 林業センサス，岩手県統計年鑑，及び，誘致企業「岩手精 密」を含めた各種聞取り調査を行った。

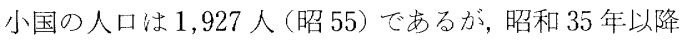
の人口流出は激しく，そのため，人口構造を極めて泵なも のにして現在に至っている。人口構造にみられる最大の特 色流齢化の進行であるが，そのなかで，特に，20才〜29 才層の男女比率の不均衡之, 45 才〜 54 才層の大きな滞留が 特徵的である。

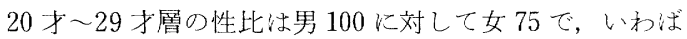
人口再生産層に括ける女子人口の不足は, すでに, 出生率 低下として現われて括り, 昭和 49 年以降, 自然減を示寸年 次が出るに至った。

一方, この階層の男子人口恃蓄積をみせ, 特に, 戦後へ ビーブーム期の人口蓄積と, 25 才 29 才層の回㷌が村落崩 壊を回避している。しかし, 女子人口の欠落により, 婚姻
機会を著しく制約し，未婚男子，を増加させている。「嫁不 足解消」が地域最大の課題とする考之は, 正に現実味を带 びている。同時に, 青年層のUターンは, 土地への財産意 識, 家制度が今だ根強く残っている左証でもある。

次に，45才〜54才層のい水わる中年層の滞留である。昭 和 56 年の老年人口係数はすでに $14.5 \%$ であるが, 現在の 年齢階層別比率では 50 才 54 才層が男女とも最も高いた め, 今後 10 年で, 急激な係数上昇は避计られない。この高 齢化を加速させているのが若年層主体の人口流出であり， その主流をなしたのが農家である。

昭和 55 年の農家戸数仙 275 戸(全戸数の $57.5 \%$ )，農家 人口は 1,263 人（全人口の $65.5 \%$ ) である。農家戸数の減 少は緩慢であるが，農家人口は，過去 10 年間で，実数 450 人と $26.3 \%$ の減少を示した。そのことが, 農業従事者の高 歯令化を加速させ, 実労働者数も昭和 45 年 1,019 人から昭和 53 年には 881 人と減少し農家構造子変質させる結果と なった。

経営規模別にみると，100 a 199 a 層が最も激しい変化 をみせた。過去 10 年間で 37 戸の減少をみせ，最も農業経 営のむずかしい層である。そのため, 規模を縮少し, 日雇, 出嫁ぎ, 臨時雇（造林が中心）など, 農外収入に道を求め ているが，不安定な分野での就労のため，離農に走らない 階層でもある。

反面，新たな傾向として，専業農家が増加している。昭 和 55 年の専業農家は 41 户である。これは昭和 45 年の 17 戸からみると大巾な増加といえる。しかし，専業農家の経 営実態をみると, 1 ha 未満層が 22 戸と過半を占め, 特に, 0.5 ha 未満の 9 戸のらち 6 戸が男子生産年齢層を持たない 農家である。0.3 ha 未満農家も 4 戸存在吉る。農業の近代化 をはかり, 自立経営の育成を衫らった農業基本法制定以来, 専業農家の増加は，いわば，それを知るバロメ一ターとい われた。農耕立地面で恵京れない地域に専業農家の増加が みられるのは，所得構造で専・兼を区別するセンサスの調 査法のせいでああるが, 後継者難, あるいは, 高踰化の進む なかで, 農外収入の道も失ない, わずかな生産物で生計を 
営む零細専業農家の増加は避けられない段階に入っている ことの現れである。同時に，それは，むずかしい山村振興
のなかに, 高齢化現象という，一層困難な問題を抱込むこ とを意味している。

常願寺川扇状地のみ流水客土が不必要だった理由

籠 瀬 良 明

富山平野の黑部川・片貝川・早月川・上市川・庄川の各 扇状地では, 昭和 26 年以降の時期に扎いて, 流水客土が行 なわれた。これに対して常願寺川扇状地では流水客土は行 なわれず今日を迎えた。このような地域的相違点の要因の らち,ここでは主として水田土壤中に鉄分が多いか否かに 焦点を执いて考察したい。常願寺川扇状地の水田土壤に鉄 分が多い理由として，常願寺川源流部，立山温泉周辺崩壊 地加の火山性岩屑の流入に関説する。特に安政 5 年 3 月 10 日，4月 26 日の土石流型洪水汇触孔て及ない。

I. 黑部川扇状地の水田で昭和 26 年 35 年, 流水客土 を行なった要因

河川水温が低いこと, 水田土壤が砂質浅耕土であること， 鉄欠乏であることなどによる冷水害と老朽化水田のため の, 著しい低反収の水田。

II. 黒部川扇状地之常願寺川扇状地の共通性 — 々 子 に流水客土を行ならものとして一一昭和 20 年代

A. 時代の影響（外来的条件）太平洋戦争上戦後の 影響……人力 - 畜力不足, 肥料不足, 米の供出制度…… どには両扇状地の水田はもとより全国的にも相違点はな い。

B. 地域的条件 水稲単作, 裏作不振などの諸条件で 虫両扇状地間に共通性が強い。

III. 本論 常願寺川扇状地で流水客土を実施しなかった 要因と考兄られる諸点

A. 人文的な諸点 常願寺川扇状地の水田地域は富 山市域叔よびその近接地域である。都市的農業の割合も高 い。住民意識々至っては黒部川扇状地の水田農村と格段に

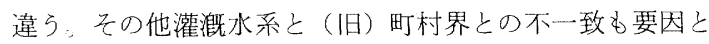
なる。

\section{B. 自然的な諸点}

1. 常願寺川扇状地の水田は冷水害田の割合が黒部 川扇状地の水田などにくらべて低い。客土の必要性が低い ことになる。

2. 鉄欠乏水田の割合が低い。この点が常願寺川扇 状地水田の大きな特性で, 客土を行わなかった最大の理由 と考之られる。鉄分が水田土壤中に多く含杰れているのは, 土壤母材が，富山平野の他の扇状地が主として花崗岩・流 紋岩などからなるのに反して，立山火山の安山岩岩屑から なり，鉄分の含有率を高めているからである。
3. 浅耕土水田の割合が低い。

4. 合口用水工事が打くれ (昭和 24 年完成), その 後も水配分に関して地域間対立が強かった。

5. 常願寺川水系内には自然性質について地域差が 大きい。黑部川・早月川の両扇状地では，その延長部に三 角州平野が無い等しいのに反し，常願寺川扇状地ではそ の延長部に広大な三角州平野が横たわる。常願寺川の水を 使用する部分についても，その西部，熊野川寄りの部分法 扇状地よりも汇濫平野的な諸性質を持つ。るた右岸扇状地 の大部分は古い扇状地であって, 洪積土壤の諸性質を持つ ことが多い。さらに人文的諸条件も加わって, 流水客土の 必要度について, 地域間に相違点が多いなど, 常願寺川水 系を一工区としてまとめあげにくく，終局的には流水客土 事業が実施されなかった。

6. 扇頂部に客土母材を得る適当な採土地が見つか らなかった。

C. 富山平野の大扇状地で流水客土を必要とする度合 いを次の順に考えることができる。黑部川扇状地 (1) 早月 川扇状地 (3) 片貝川扇状地 (4) 庄川扇状地 (5) 上市川扇 状地(2) 常願寺川扇状地

（）内の数字は実際に流水客土事業が行なわれた順序。

IV. 淿整備事業との関連

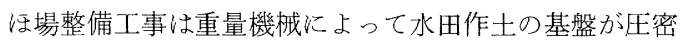
されるため, 結果的には扇状地土壤の持つ過度の透水性を 緩和寸る効果がある。流水客土工事の発想は終戦直後であ る(昭和 24 年には早くも黒部川扇状地で客土のための試験 田が富山県農業試験場の手で進行していた)。その段階では 常願寺川水系の水田地带中, 少なくとも扇状地の扇央部は, 他日流水客土工事を行なら企てはあったように思わ机る (確証については目下調査中)。客土は県営事業なので当然 緊急度に上る実施順序があった。緊急性の高い庄川扇状地 にしても客土工事を終了したのが昭和 52 年であるから, 常 願寺川扇状地恃実施するとしてもとの後ということにな る。

然るに昭和 39 年前後より富山平野では恃掕整備事業が 進行し, 常願寺川扇状地でも活場整備がスタートした。こ のようにして客土工事に着手するチャンスを得ることな く, 今日に至ったのである。 
前報（地理予，14・16）にひきつづき，岡山市北部地区 ならびに津山線沿線（岡山〜津山間）に扣いて，次の諸点 を検討した結果を報告する。1，中新世海進時の古地理・ 古地形（公海であったか，多島海であったか）。2，後中新 世の隆起過程（東西軸をもつ曲隆・曲降の久ならず南北軸 をもつ不動帯が存在すること)。3. 小起伏面の区分論・成 因論（数水準の準平面遺物々及るか。寸べて中新世層基底 の剥離面とするか)。調查は, 中新統と山仯利統との層序区 分の再検討, 中新統・山砂利統の残存状沿亡小起状地形面 との関係に重点を置いた。

従来，中新統（海成砂層・シルト層を典型とする）と山 砂利統（すべて河的砂碩層）とは時代を異にするものとし て塗色されているが不整合露頭は記載されたことがなかっ た。岡山市北方辛香峠 (山砂利勫標式地) の西方 $1.5 \mathrm{~km} の$ 菅野（loc. 1) に执いて，塊状無層理の青灰色シル:層を明 瞭な境界をもって和㧈う砂碩勫の露頭がある。しかし，そ の北西方 $0.7 \mathrm{~km}$ の和田 (loc. 2) では, 注注同一高度に碩李 ごり砂層の露頭がみられるから，両者を不整合とする積極 的資料とはならない。両者は一連である(川砂利統とされ たものは中新統の基底相）と考えられる。

津山線浻線には，上記の 2 様の岩相をもつ中新統がほぼ 連続して分布して扣り，その基底高度は現谷底面と注ぼ異
ならない。したがって，岡山一津山間の津山線に沿ら地带 法，曲隆していないことになる。

その基底高度より, 中新統の最大層厚（児島湾底下に現 存する 6 層準の全層厚 $301 \mathrm{~m}$ ) を我って中新世海進時の古 地形を復原すると，岡山市北東方の金山などは，当時より 島をなしていたことになる。すなわち，中新世海進によっ て公海が生じたのではなく，多島海であったことになる。

幸香峠北西方 $5 \mathrm{~km}$ 津高町日応寺の衝上断層 (loc. 3 , 走 向は $\mathrm{N} 45^{\circ} \mathrm{E}$, 中新統基底砂砂層に基盤岩が衝上。標式露頭 での垂直変位量 $2.5 \mathrm{~m}$ 以上）は吉備山地の曲隆を示唆する 資料とされてきた。しかし，方の周囲の中新統基底高度分 布（もともと起状方基盤岩にアバットしている）は断層 を挾んで大きく異ならない。さらに北西方の花佐，矢田で 蛙しろ低くなっている。

いわ功る隆起準平原面状の小起伏面における中新統の残 存状況恃，小起作面の凹所にの及残存可ること，残存する 層厚が小さい特徴があり, 小起伏面は中新統基底面の剥離 面（中新統之基盤岩之の差別侵蝕による）と考光られる場 合が多い。好例としては, 岡山书益田北西方のゴルフ場, 日応寺南方岡山大学農学部農場付近, 建部町安ヶ屹・京 尾・峠 (嘼), 神目北西方別所, 久米南町豊坆などである。

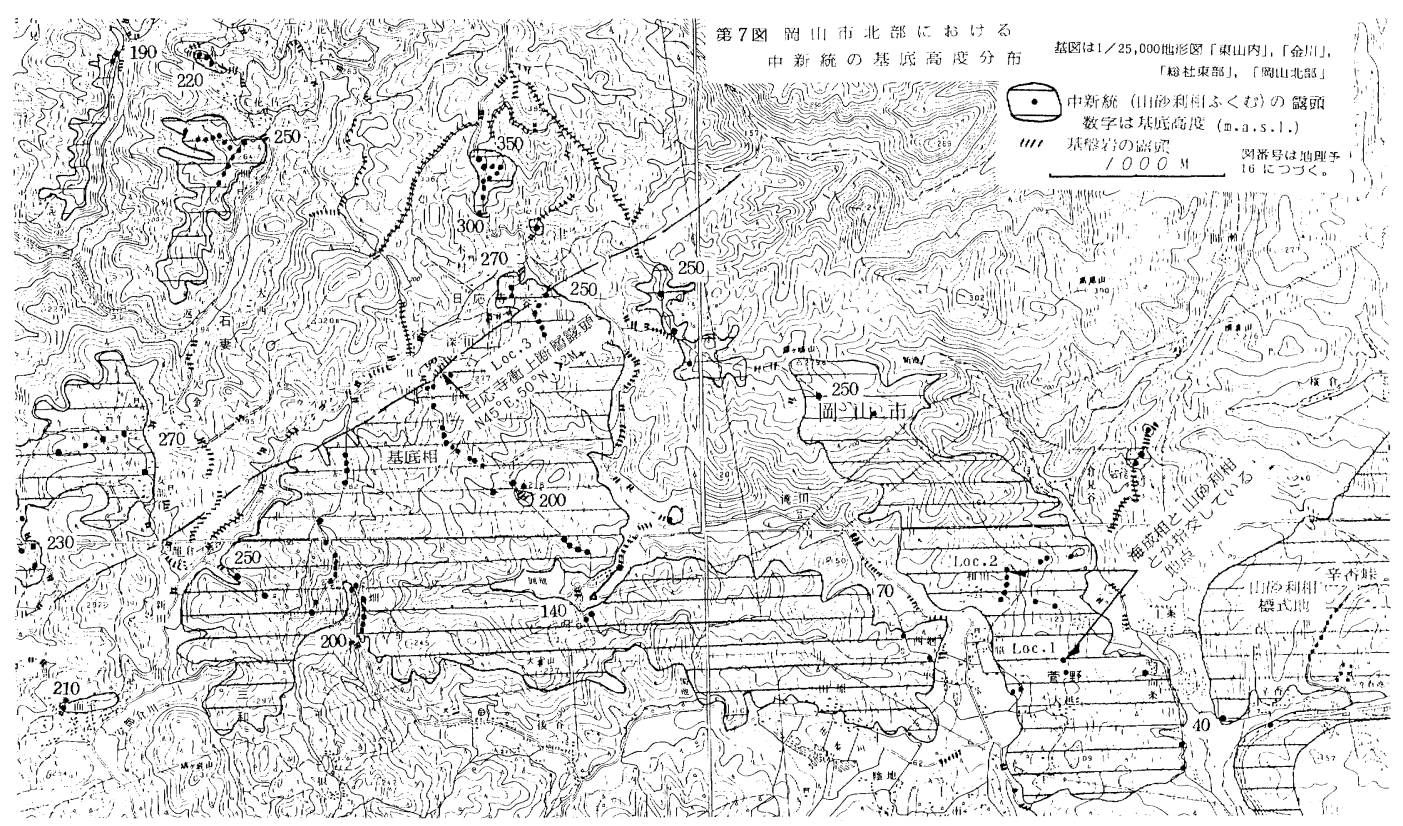


間引そついて

前回の報告 (東北地理 33 巻 3 号, 要旨) では主として従 来の研究の方法上の不適切々，そのための資料の選択の不 適切をあげ，再検討の必要を述べた。今回は，昭和 10 年に 民俗学徒を動員して行初たききとりを中心に，間引の近 代汇扣ける全国的分布を概観してみる。本資料は母子愛育 会編（1972）：全国産育習俗集成として刊行されている。た だし, 間引及び陏胎の項目の報告は, 北から「山形」「茨城 「静岡」「大阪」「京都」「徳島」「佐賀」の 7 府県を欠いて いる。これを表に示した。

第1 表の地域差を隋胎についての分布を援用しつつ分析 すると，次の諸点が添淁推定できる。

1. 間引は全国的に列島の南北両端に近い地方に, 濃密 に行われたようにみえる。

2. これに反して，䧺胎はより旧文化の中心に近い地域

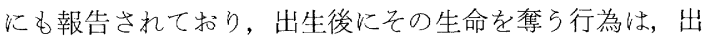
生前に姿をみ妨ちち処理するよりも原始的で心に忍びない
と考光られたらしいことが考觉られる。

3. 間引の報告されない地域仙，それが存在しないとみ るよりも，口外すべからざるものという認識か慟いたとみ る方が適切である。

4. 上記の根拠として，間引の方式をみると，压死の上 らな特に腕力によって強制的に生命を失わせる方式が，や はり周辺地域に卓越し，中心汇近くなると人力をあまり加 亲ない溺死・窒息死が多い傾向が認められる。

5. 同様の傾向怯, 隋胎方法にもあら方水, 母体に危険 の多い物理的方法を用いる原始的手段快周辺部々多く, 薬 物による内部からの中絶方武はやはり文化的中心に多いよ らでこれは，一般的な文献による中絶法の記載とも一致 する。

6. 間引の起源は少くも中世に溯り，近現代と異なる意 識が支配したことは，南蛮史料から確認できる。

間引・阷胎とその方法の地域的分布

\begin{tabular}{|c|c|c|c|c|c|c|c|c|c|}
\hline \multirow{2}{*}{ 府 } & \multirow{2}{*}{ 県 } & \multirow{2}{*}{ 名 ${ }^{11}$} & \multirow{2}{*}{ 間 引 } & \multirow{2}{*}{ 埴 胎 } & \multicolumn{3}{|c|}{ 間 引方 式 ${ }^{2)}$} & \multirow{2}{*}{ 值胎法 } & \multirow{2}{*}{ 避 妊 法 } \\
\hline & & & & & 多 & 中 & 稀 & & \\
\hline 青 & & 森 & 0 & 0 & 压 死 & & & 物 理 的 & \\
\hline 岩 & & 手 & 0 & 0 & 溺＼cjkstart死 & 圧．死 & & 物理的・薬 & 民間療法・炎 \\
\hline 宮 & & 城 & O & 0 & 窒息死 & & & & \\
\hline 秋 & & 田 & 0 & 0 & 窒息死 & 溺 死 & & 物 理 的 & 祈 \\
\hline 福 & & 島 & 0 & 0 & 同 上 & 圧 死 & & & 呪 \\
\hline 栃 & & 木 & 0 & 0 & & & & 物理的・薬 & 民間療法 \\
\hline 群 & & 馬 & 0 & 0 & 窒息死 & 生 死 & & 薬・物理的 & 同上 \\
\hline 埼 & & 玉 & 0 & 0 & 圧＼cjkstart死 & & & 物 理 的 & 民間療法・呪術 \\
\hline 千 & & 葉 & 0 & 0 & 窒息死 & & & $?$ & 呪術 \\
\hline 東 & & 京 & 0 & & & & & & \\
\hline 神 & 奈 & 川 & O & 0 & & & & 薬 & 呪 \\
\hline 新 & & 潟 & 0 & 0 & 圧 死 & & & 物 理 的 & 民間療法・祈願 \\
\hline 富 & & 山 & & 0 & & & & 薬・物理的 & 民間療法 \\
\hline 石 & & 川 & & 0 & & & & 薬 & 民間療法 \\
\hline 福 & & 井 & 0 & 0 & 圧 死 & 溺 死 & 窒息死 & 薬 & 民間 療 法 \\
\hline 山 & & 梨 & 0 & 0 & 同 上 & 窒息死 & & 薬・物理的 & \\
\hline 長 & & 野 & 0 & 0 & 同 上 & 同上 & & 薬・物理的 & 民間療 法 \\
\hline 岐 & & 阜 & 0 & 0 & 溺 死 & & & 薬・物理的 & 祈願・呪術 \\
\hline 愛 & & 知 & 0 & 0 & 窒息死 & & & 物 理 的 & 祈 \\
\hline$\equiv$ & & 重 & & 0 & & & & 薬 & 祈 \\
\hline 滋 & & 賀 & & 0 & & & & 物 理 的 & \\
\hline 奈 & & 良 & 0 & 0 & 窒息死 & 餓 死 & & 物 理 的 & 祈 \\
\hline
\end{tabular}




\begin{tabular}{|c|c|c|c|c|c|c|c|c|c|}
\hline \multirow{2}{*}{ 府 } & \multirow{2}{*}{ 県 } & \multirow{2}{*}{ 名 $^{11}$} & \multirow{2}{*}{ 間 引 } & \multirow{2}{*}{ 值 胎 } & \multicolumn{3}{|c|}{ 間 引方 式 ${ }^{21}$} & \multirow{2}{*}{ 值胎 法 } & \multirow{2}{*}{ 避妊 法 } \\
\hline & & & & & 多 & 中 & 稀 & & \\
\hline 和 & 歌 & 山 & & 0 & & & & & \\
\hline 鳥 & & 取 & $\mathrm{C}$ & 0 & 窒息死 & & & 物理的 - 薬 & 祈願 - 众 \\
\hline 島 & & 根 & $\bigcirc$ & 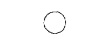 & 溺 死 & 窒息死 & & 物理的 - 薬 & 同上 \\
\hline 岡 & & 山 & 稀 & 0 & 压 死 & 同上 & 溺死 & 物理的 $\cdot$ 薬 & \\
\hline 広 & & 島 & 0 & 0 & & & & 薬-物理的 & \\
\hline$山$ & & П & & 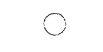 & & & & 物 理 的 & 呪術・祈願 \\
\hline 科 & & 川 & $\bigcirc$ & 0 & & & & 同上 & \\
\hline 愛 & & 媛 & $\bigcirc$ & $\mathrm{O}$ & 窒息死 & & & 同上 & 呪 \\
\hline 高 & & 知 & 0 & & & & & $?$ & \\
\hline 福 & & 岡 & 0 & ○ & 压 死 & & & 薬 - 物理的 & 呪 \\
\hline 長 & & 崎 & ○ & $\mathrm{O}$ & & & & 物 理 的 & \\
\hline 熊 & & 本 & 0 & & 圧 死 & & & ? & \\
\hline 大 & & 分 & 0 & & & & & $?$ & \\
\hline 宮 & & 崎 & $O$ & $\mathrm{O}$ & 窒息死 & & & 物理的・薬 & \\
\hline 鹿 & 览 & 島 & $\mathrm{C}$ & 0 & 同上 & 压: 死 & & 薬・物理的 & \\
\hline 沖 & & 繩 & $\bigcirc$ & $\bigcirc$ & 同上 & 溺 死 & & 薬・運動 & 呪 \\
\hline
\end{tabular}

（注）1）記載なさ府県は回答なきもの

2) 記載内容より筆者の判断して分類したもの

本表屿子愛青会編（1977）：全国産育習俗資料集成により作成した。

\section{塩田の工場用地への転用について \\ 一山口県下箱涗田の場合一}

重 見之雄

塩田の転用という場合の多くは，塩業整備などによって 一旦廃止された塩田の転用を指すが，稼動中の塩田が直ち に転用される例は少ない。この下松塩田はその少ない例の 一つである。ここの塩田が全部廃止されるのは, 昭和 34 年 の第 3 次塩業整備によってでるが, 塩業組合が経営する 塩田でありながら, 大正 10 年以来法人所有であり, しかも 小作塩田のあったことなど、ユニークな点である。

明治 38 年 (1905) 専売制施行当時の塩田は, 笠戸湾岸に 沿って北西から南東に延びて打り, その面積は約 100 ha 余 りでめった。その開発は古いもので元禄 2 年 (1689), 新し いものは嘉永 5 年（1852）といずれ本幕末李で汇開発さ れていた。

明治時代の所有者は，部分的にしか明らかでないが，東 南部の宮ノ洲 15 塩戸, 約 30 ha は明治 21 年 (1888) K旧德 山藩主から矢島家に所有権が移っている。同家は石炭問屋 や塩問屋を営み, 塩田は 15 人の小作人に貸与していた。北 西部の西潮上, 一八桝, 二八桝の所有者も, 明治初期の県 会議員などで，かなりの地主階級であったと思われる。こ れを含めて結局下松塩田全部を大正 6 年に久原家が全部買
收した。久原家がどのような生い立饦よるものかは明ら かでないが，同年に塩田の他にかなりの面積の農地その他 も買収したようである。

転用は東南部の宮/洲から北西に向かって順次行なわれ たが，北西部の西潮上，一八栘，二八柝は昭和 34 年の第 3 次塩業整備まで稼動していた。宮!洲には早くも大正 6 年 に日本汽船 $\mathrm{KK}$ 笠戸造船所が創業を開始したが，間もなく 造船不況に遭遇し, 大正 10 年には日立製作所に合併さ礼て 今日に至っている。湮济中央部，大字西豊井の新川にある 恵宝屋浜ら大正 8 年に大蔵省の所有地になり, 同年ここに 輸入原塩を精製する製塩工場が設立された。さらに昭和 4 年には日立製作所が立地した宮, 洲の西隣の宮浦に日本石 油が立地した。たまたま同社は鶴見製油所を建設後, 西日 本にも製油所を建設すべく敷地を物色中であった。そして 当時の下松町長や町議会をはじめ, 久原家や前所有者の矢 島家までが協力して条件整備に当たった。

当初 100 ha 余りだった塩田か，昭和 8 年には 42 ha 余り になってしまう。これは工場用地への転用のみならず，昭 和 5 年の第 2 次塩業整備のために約 32 ha が廃止されたこ 


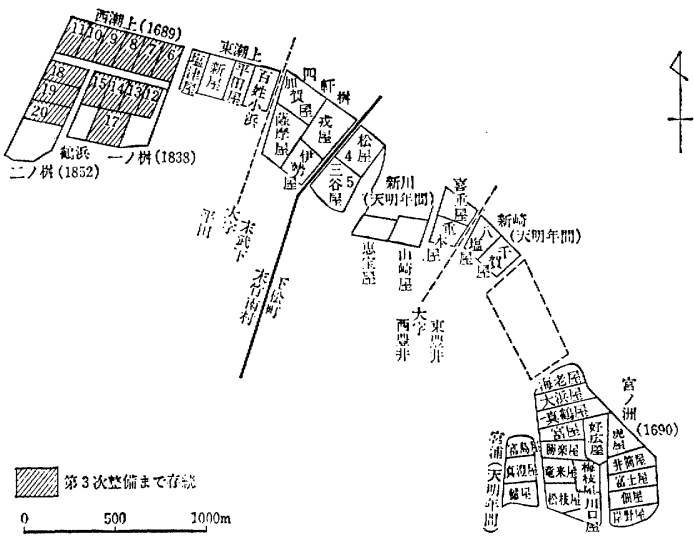

専壳制施行当時の下松塩田

(「三田尻収納所管内地図」による)

とも手伝っている。昭和 9 年には宮ノ洲塩田に立地した日 立製作所の北隣に東洋鋼板が立地した。この工場が当初立 地した所は, 塩田としての開発に失敗して水田化されてい た所であるが，その後の工場の拡張でやはり塩田を潰して いる。第 2 次塩業整備によって廃止された塩田もその後港 湾用地や工場用地になった。

大正 6 年の久原家の買收地は大正 10 年には $\mathrm{KK}$ 久原用 地部の名のもとに法人所有となり，昭和 18 年に下松土地 KK と改称して今日に至っている。稼動する塩田に関して, 塩専売法に定めるかん水製造権は, 塩田を経営する各塩業 者に与兄られ，かれらが集まって下松塩業組合を組織し， 塩製造権は塩業組合に与えられていた。そして塩業組合が 塩田の所有者である下松土地 KK との間に塩田の賃貸契 約を結び，小作料として年間の塩の生産量の 2 割にあたる

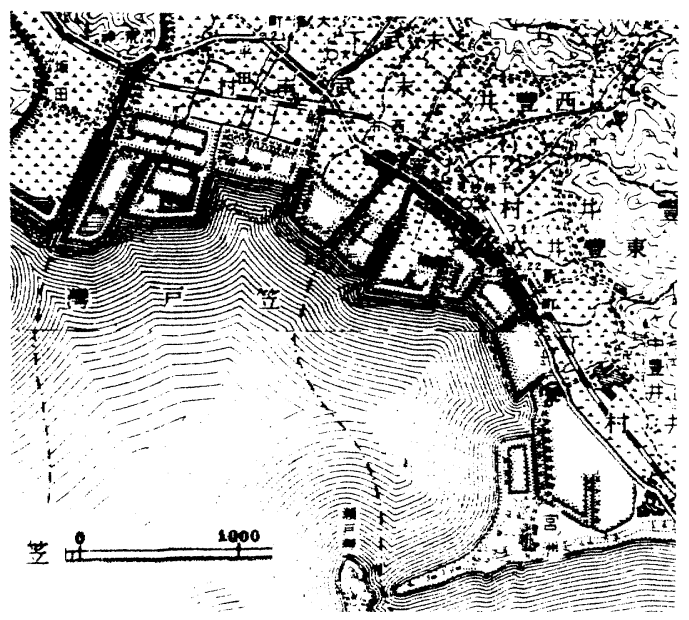

1899（明治 32）年の下松

（5万分の 1 地形図「德山」「室積」ともに 1899 年測図）

金額を支払っていた。しかし，昭和 34 年の第 3 次塩業整備 によって残る約 27 ha 全部の塩田が廃止されるにあたって 梖貸契約は解除され，塩業組合も解散した。

第 3 次整備による廃止塩田にはその後, 部分的にではあ るが自動車部品製造, 石油関係などの中小工場が立地した。 大さなものでは, 昭和 36 年に中国電力の新鋭火力発電所の 立地がある。敷地面積は約 43 万 $\mathrm{m}^{2}$ で, 廃止塩田沖の海面 も埋め立てられ, 昭和 39 年 10 月から操業を開始した。最 西端の二八桝塩田 20 番浜の沖では, ツルガハマ栽培水産 $\mathrm{KK}$ が車エビの養殖を始め, 火力発電所から温排水の供給 を受けて，発電と養殖の共存共栄を図っている。

東北に和ける海面養殖業の最近の変化

河上税

第 6 次漁業センサス（1978 年）の結果によると, 東北に 打ける海面養殖業階層の経営体数は 11,131 を数える。これ を前回の 5 次(1973 年) と比較すれば 19.5\%の減少である。 この階層の経営体数は 3 次 (1963 年), 4 次 (1968 年), 5 次 まで増加を続けていたが，6 次から減少に転じ，4 次の実数 以下に隇少している。

これを業種別にみれば，力キ養殖業階層の経営体数だけ が 5 次から 6 次に $32.7 \%$ も大きく増加している壮れぞ，，

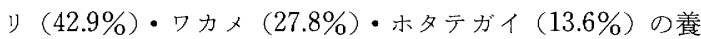
殖業階層の経営体数は, いずれも著しく減少している。こ れを地域的にみれば, 太平洋側が総数の $99.4 \%$ を占めてい るのに, 日本海側は男鹿半島沿岸に, ワカメとノリの養殖
業階層の経営体が僅かに分布するに過ざない。養殖適地の 多い太平洋側の浅海では元来養殖業が盛んであったが，適 地の少ない日本海側では 5 次に初めて, 海面養殖業階層の 経営体が出現した。

江戸時代末から始められた,り養殖業は, 現在松島湾の 内外を中心として，北は陸奥湾の平内町小湊から，南は松 川浦の相馬市磯部まで分布している。この階層の経営体数 は 4 次の 5,333 をピークに, 5 次・ 6 次と引き続き激減して いる。主産県の宮城では 5 次から 6 次に $43.8 \%$ も経営体数 が減少している。これは全国的なノリの生産過剰による安 值に加之て，松島湾内の不作に起因している。

ワカメ養殖は1960年代に普及し, 現在東北に打ける海 
海面養殖業階層の経営体数の推移

\begin{tabular}{|c|c|c|c|c|c|c|c|}
\hline \multicolumn{2}{|c|}{ 海区県別 } & 1963 年 & 1968 年 & 1973 年 & 1978 年 & $\begin{array}{r}1978 / \\
1963\end{array}$ & 主な業種 \\
\hline 青 & 森 & 156 & 194 & 1,461 & 1,349 & 8.6 & ホタテガイ \\
\hline 岩 & 手 & 1,912 & 4,581 & 5,359 & 4,216 & 2.2 & $\begin{array}{l}\text { ワカメ・カキ } \\
\text { ホタテカイ }\end{array}$ \\
\hline 宮 & 城 & 5,234 & 6,484 & 6,727 & 5,252 & 1.0 & $\begin{array}{l}\text { ワカメ・カキ } \\
, y\end{array}$ \\
\hline 福 & 島 & 314 & 288 & 245 & 241 & 0.8 & , リ \\
\hline 秋 & 用 & - & - & 38 & 70 & & \\
\hline 東 北 & 計 & 7,616 & 11,547 & 13,833 & 11,131 & 1.5 & \\
\hline 全 & 国 & 64,838 & 72,174 & 61,347 & 48,413 & 0.7 & \\
\hline $\begin{array}{c}\text { 対 全国 } \\
(\%)\end{array}$ & & 11.7 & 16.0 & 22.5 & 23.0 & & \\
\hline
\end{tabular}

（注）日本海北区に含まれる青森県と山形県には海面養殖業階層の経営体が存在しない。

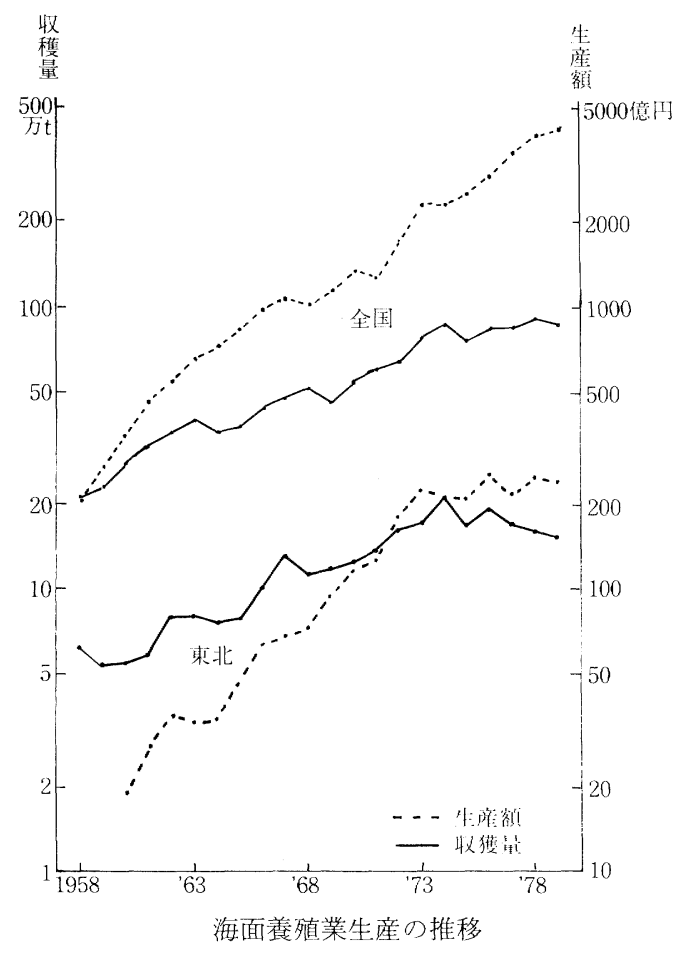

面養殖業階層の経営体総数の $41.7 \%$ を占めている。この経 営体は三陸地方中部を中心として，北は津軽海陕に望毛方 つ市関根浜から, 南は牡鹿町網地島まで分布している。こ の経営体数は 3 次・ 4 次・5 次と増加し，6,437 を数えピー クとなり,6次から減少に転じている。ワカメも生産過剒に よって安值となったためで, わが国最大の生産県である岩 手では, 5 次から 6 次以経営体数が $30.5 \%$ も減少し, これ に次ぐ生産県の宮城も $22.4 \%$ 減少している。

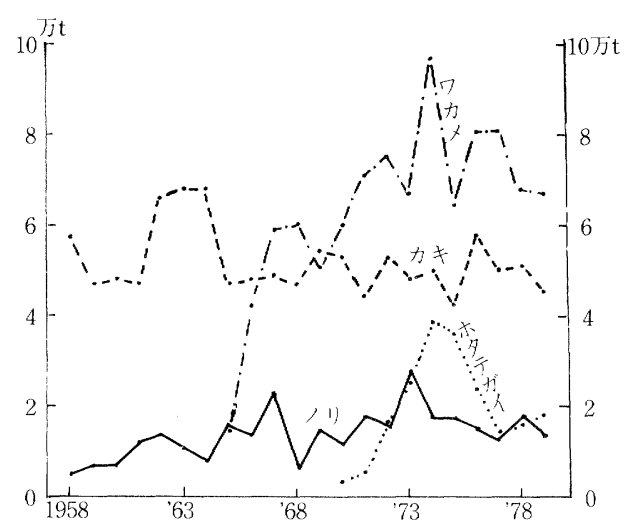

東北に和计万主要な海面養殖業収獲量の推移

大正時代から養殖されたカキは，現在北は陸奥湾の青森 市から，南は松川浦の磯部杰で経営体が分布し，三陸地方 中部から松島湾に至る浅海がカキ生産の中心地区である。 経営体数は 3 次から 4 次にかけて減少したが，5次から増 加に転じ, 6 次も引き続き増加している。特に最大の生産県 の宮城では, 5 次か56 次に経営体数が $20.4 \%$ も増加して いる。力キの生産は, 泀ぼ横ばいであるが, 安定した需要 に支えられて, 高価格で取り引きされているため, 経営体 数が増加したのである。

ホタテガイの養殖は 1970 年代に普及し, 経営体数は 5 次 にピークに達した。これらは北は津軽海峡に望む三厔村か ら南は牛鹿町大原李で分布しているが, 陸奥湾は最大の生 産地である。近年養殖ホタテガイの撆死による生産の減少 や, 貝毒の発生による出荷の一時停止などによって経営体 数が減少している。しかし広い養殖適地をもつ陸奥湾では, 経営体数の減少は僅かである。

上記の 4 業種以外に, 近年著しい生産の伸びをみせてい 
るものに、コンブ・ホヤ拈よびギンザケの養殖業がめる。 コンブ養殖は三陸地方中部を中心に盛んになりつつある。 なた，ホヤの養殖は三陸地方南部を中心に盛んである。こ れらをワカメやカキの養殖に加えることによって, 経営の
安定が計られつつある。なお，ギンザケの養殖は，漁業会 社と漁民の協力によって, 1977 年頃から志津川湾で始めら れたもので，今後の発展が期待される。

\section{横手盆地の切花キク栽培}

\section{菊 池 勝 俊}

本研究は，横手盈地に抢ける花卉調査の一環として切花 キクを取り上げ，栽培の経緯と現状，経営と需給などをと 扣して，栽培の実態とその特色を明らかにすることを目的 としている。

調査は, 東北農政局秋田統計報事務所大曲・横手・湯沢 各出張所, 秋田県農産園芸課, 角館・大曲・横手・湯沢各 農業改良普及所の統計資料を用いたほか，現地調查和よで 主要農家への聴さ取り調査を和こなった。またこれに，花 卉生産者と盆地内五高校の父兄とを対象としたアンケート 調查を加えた。統計年度は，1979年を中心とした。

結果峙, 次の諸点に要約できる。

1. 切花キク栽培は, 転作に伴ら歴史の新しいものであ る。栽培農家は㿽地内に広く分布し, 個別的に拡大してい る。

2. 裁培の経緯には、, 花卉栽培先駆者達, 技術研修者達, 露地キク栽培先駆者達によるものがある。栽培の主体は技 術研修者達である。
3. 栽培は露地を中心とし, 主として転作用において行 われている。施設は無加温パイプハウスを中心としている。 両者之も，年次や個人による収益の差が著しい。

4. 切花キクは, 水稲の複合部門を構成与る。高度な技 術や水稲との労働力競合によって, 栽培面積の拡大が防げ られている。

5. 出荷量の壃加は, 県内市場に扣ける消費量の拡大に 支光られている。盆・彼岸の消費が高く, 花屋, 種苗店, 雑貨・小売店などからの購入が多い。

6. 地区別特色は次のと扣りである。

大曲・仙北：面積の増加が大きく，転作面積率が高い。 中仙町に集団栽培がみられる。

横手・平鹿：施設面積率が高く, 面積の增加率我大きい。 十文字町に出荷の集団化がみられる。

湯沢・雄勝：年次による面積の変化がみられる。導入が 比較的古く, 転作面積率が低い。

\section{北上川流域に抢沪る農業の変化}

\section{青 柳 光太郎}

本研究では, 分析対象地域を一地形単位である北上川流 域にとり，1960年から 1975 年末での農業の変化を各年次 農林業センサスを資料としてみてゆくことにする。

総農家数の推移, 専業, 兼業別, 兼業種類別, 経営耕地 面積, 水田率, 畑地率, 樹園地率の変化過程の順にみてゆ $<0$

分析対象地域は図に示した。岩手県・宮城県合せて 9 市 47 町 10 村の地域である。

総農家数の推移をみると, 1960 年の 141,359 戸から減少 し 1975 年には 136，928 戸となっている。15 年間の減少率 は $3.1 \%$ であり，全国の値（18.2\%）より小さい。

専業・兼業別にみると, 専業農家率は 1960 年の $40.3 \%$ から減少して 1975 年には $8.0 \%$ となっている。全国と比較 すると 1975 年時点で全国水準を下廻るよらになり，急速な 総兼業化傾向が窺われる。しかし, 第 2 種兼業農家率は全
国のそれより小さく，深化の程度は弱い。兼業種類別に兼 業化の進行状況をみると, 当地域の兼業化は, 地元で就労 する (雇用される) 形態, 即ち恒常的勤務, 日雇, 臨時雇 の増加によってもたらされたといらことができる。肪町村 単位に兼業種類の組又合せを修正放一法によって求め た。1960年の規則性を欠いた分布から, 1975 年には, 市域・ 郡の中心地を中心之した恒常的勤務の多い地带, その外緣 部の日雇・臨時雇の多い地带といら構成へ変化してきてい る。

経営耕地面積は, 1960 年の 176,214 ha 加ら堌加し 1970 年には185, 176 ha となり，その後減少して1975年には 181, 326 ha となっている。水田率は 1960 年の $65.6 \%$ から 增加し, 1975 年には $79.6 \%$ となっているが, 逆に畑地率は $32.0 \%$ から減少して $18.1 \%$ となっている。樹園地率は 2.5 $\%$ 前後上大きな変化は示さない。総体的に, 1960 年から 


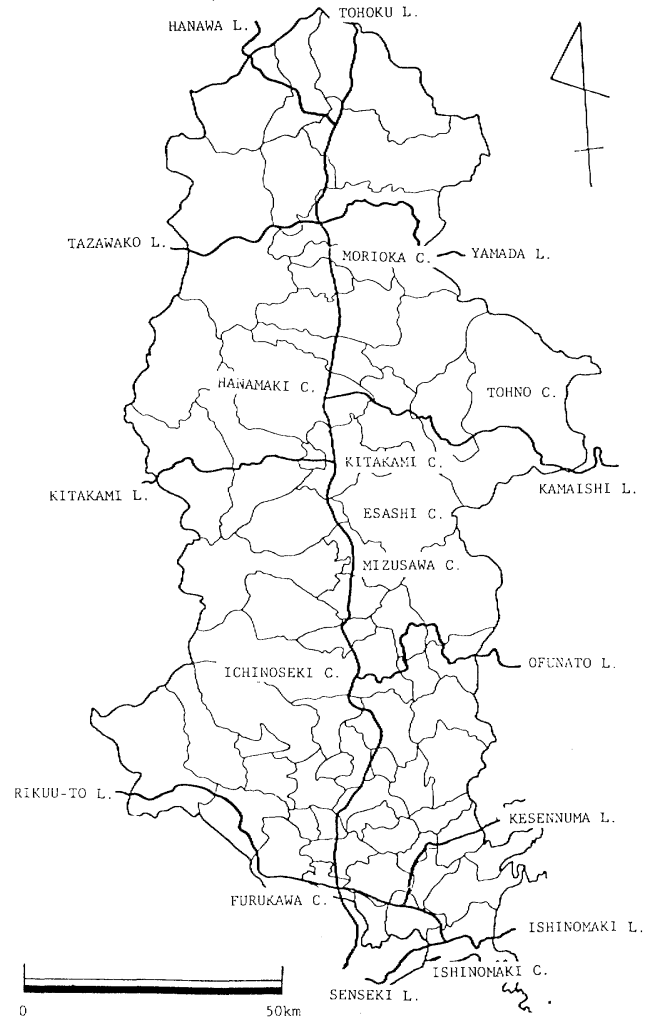

1975 年までの期間は水田率が増加し, 烟地率が減少する。 特にその傾向は 1960 年代後半に著しい。継続した水田化傾 向がみられるが，1970年代に入り鈍化する傾向にある。

対象地域の農業を総合的にとらえるために 1975 年時点 についての主成分分析を行った。変量として，土地利用， 専業・兼業, 畜産などの 17 変量をとりあげた。矢の結果, 固有值 1.0 以上の 5 つの成分が抽出された。第 1 成分は, 水田単作経営十小規模な豚・鶏飼育農業の成分, 第 2 成分 は都市部に括计る農業の成分, 第 3 成分俚零細規模農業の 成分，第 4 成分は耕作主体の専業農業成分，第 5 成分は肉 牛飼育農業の成分である。成分得点の分布を合世て考光て 好ると, 当地域の農業は水田単作が主体であり, これに兼 業機会湄覀れず畜産が導入されていない山間支谷地域の 零細規模農業といった構成になっているということがでさ る。1960 年代の大幅な水田化傾向が 1970 年代の脱水田化 傾向を打ち消し，このような結果が出たと考兄られる。北 上川といら大河川流域をとって農業構造をみた場合, 水田 単作の成分之雾細規模農業の成分だけではなく，他に畜産 関係成分（当地域の場合，肉牛飼育農業が第 5 成分として 抽出されたが)，畑地農業成分，樹園地農業成分などが抽出 されるべきであると考えられる。近年, 農家単位の複合経 営が再認識されつつあるが，大河川流域といったレベルで の土地条件を考慮に入れた複合経営の展開，つまり農業経 営に扮沙る地域分化が促進される必要がある。

\section{都市問題として農業・農村問題}

わが国に扣いては市街地化した部分にかなりの農用地が 残存しているし，いっぽうでは都市の最外縁部でつねに都 市的土地利用への転換がはかられ，いわゆるスプロールが 進展している。これを防止する観点から大規模な二ュータ ウンが計画されたけれども, ニュータウン計画区域周縁部 や内部に新たな問題をひきおこした。それは農業や農村と 都市計画之の矛盾の噴出である。いまや都市計画をたてる にあたって，従来のような農業計画・農村計画無しのまま で隹都市計画そのものの遂行が大矛盾を抱えることにな りこの点であらたな都市問題をひき扢こさざるをえなく なっている。それは都市問題として把握されなければ, 解 決の不可能な農業・農村問題と言ってもよいであろう。そ の典型的事例を多摩ニュータウンにみることができる。

1965 年 12 月䄪 3,000 ha に新住宅市街地開発事業に関す る都市計画決定告示がなされすでに 16 年を経過した。約 4 分の 1 完工したが事業末認可地区が 417 ha (13.8\%) ある。 なかでも第 19 住区予定ではいわゆる酪農問題が括こり, 反 対運動が現在継続中である。これらの反対運動の過程を分
析することによって主題にせまることが可能である。これ らは請願・陳情の形態をとっているが，記録文書として残 されていることが，彼等の自己認識の過程を知るにも都合 が良い。最初の陳情に回答が出されているが，これは 90 名 にたいしてなされたものであっても，全 2,000戸の農家に 例外なしに示されたものと考えてよい。3,000 ha の土地全 部を井い込久, 農業補償はいっさいやらない; 離農・転業 の場合は相談にのったり，職業紹介や訓練の指導を考学る が，新住法によって申し出のあった場合の夕；しか子施行 者の事情の許す限りで, やるやらないは施行者の自由; 農 業を継続して生計をたてることは許されない; 宅地は一定 面積優先譲渡; 農業以外の業務につく場合で, しかも自己 の生計維持に必要な場合のみ業務地を一定面積優先分譲と いうものであった。これは 2,000 戸の農家の土地買収に対 する強力な抵抗を引き起こした。その結果集落地を中心に 土地区画整理事業 452 ha が導入された。しかし優良農業地 区からの反対は強力で，とくに旧由木村からのものがそう であった。酪農の発祥地堀の内地区の請願は 1966 年 6 月以 
降更新・継続が扣こなわれ，現在でも未決である。地区除 外要求の運動は, はじめは主体者の意志や主張が明確でな かったが，これは必ずしもほんねで反対でない者も混じっ ていたからである。この地区の土地買収のはじまった 1973 年末を契機に, 反対運動性酪農業者のみにしぼられて, か えって彼等の自己認識を呼び持こした。それは 1975 年の請 願書に明瞭にあらわれてくる。

一般的には, この時点で運動は開発者の「論理と戦略」 に押しつぶされるのであるが，そうはならず，外部へ向っ て拡大・伝播し，広域化していった。地区外の八王子みぞ りの会など 139 名の農業専業経営体とその後継者達による 請願となってあらわれ, 現在でも東京全域の市民運動に発 展していく兆しをみせている。

これから農業後継者達も, 堀の内地区の運動を自分達の ものと理解したから支援を送ったのであるが，両者に共通 しているのは, 農業生産力の担い手としてのプロ意識であ り, 農業生産力の発展を促するような, 農業を産業活動の 一部門とするような産業政策・都市政策ないしは地域開発 政策が必要であるという認識である。従って請願では都市 計画の考え方, 理念まで批判の対象になり, 高度経済成長
政策が急激に人間疎外を生み出し, 都市計画がそれの一役 を担っていたことを批判し，都市計画・開発政策がいった い誰のためにされるべきか, 開発とは何かを問いかけると ともに, 開発の進め方にも厳しい批判が展開されている。 また，都市や都市政策に対する当局の考え方は市民のそれ とはかなりの落差のあることが指摘されている。従って, 都市と農村の調和を綜合的にはかるといら新しい大部市構 造の形成には，現行の都市計画を根本から考えな㧤す必要 にせまられていると言えるのではないだろうか。

急激な都市化と人口の急速な都市集中によって，とくに 大都市近郊農村は急速に都市内部に包摂され，農業は都市 農業に急速にまた強制的に変質させられつつあり，農業者 も農業者のまま，いまや都市住民の一員となったと考えら れる。近郊農村は都市農業を含みながらも大部市の一地帯 を形成することになった。そこでの農業者は, 大都市の住 民として農業生産に携わる大都市生活者なのである。こう いう状況の下で「画一的・機能的」に農用地や農業を都市 的土地利用や産業に变え, 「農村」を「都市」にしてしまっ てよいであろらか。付随して扣こる都市問題が激化するば かりではないのだろらか。

\section{外山川上流地域の段丘・湿原堆積物の堆積環境に関する考察}

$$
\text { 菅原啓・山中三男 }
$$

北上山地外山高原内の外山川源流・上流地域には, 低起 伏の高原内に湿原を伴ら緩斜面や河岸段丘が形成され，そ れらの地形面は高位より外山I～IV の各面に分けられる。 本報告ではこのうちの外山 II 面に当る外山川上流葉水付 近の段丘化した緩斜面および蛇塚湿原を有する同川源流部 の緩斜面等の堆積物の堆積環境を，その層相・花粉分析学 的観点から予察的に考察する。

【葉水地区]堆積物は確認される部分で延層約 $13 \mathrm{~m}, 62$ 層におよび，それらの層相から計 13 群(らち3 群について は8 亜群)にまとめられる。

堆積物上半部に当る第 $\mathrm{I} \sim \mathrm{IV}$ 群, $\mathrm{V} \cdot \mathrm{VI}$ 両群中〜下層, VII 群等は, 表層物質 (主に火山噴出物起源)のマスムーブ メントによる斜面婎積物である。いずれる粘土質マトリッ クスを伴ら角礫層・角礫混り粘土層等から成り, 明膫な colluvial deposits の層相を示す。

これに対し堆積物下半部は湿性堆積環境をも含めた alluvial deposits に当り，その中には腐植集積の顕著な部 分と, そうでない砂砂質部分とがある。前者は泥炭・泥炭 質粘土層等を成しその層相から湿原的な堆積条件を考光得 るが, その堆積様式として i ) 腐植集積にとって異物質と いえる細粒砂質物質の供給をかなり頻繁に受けてきたもの (第 V ・ VI 両群表層, VIII 群, IX-1 ・ IX-3 - X-1 • XII -2 各亜群等)，ii）腐植集積を妨げない程度の頻度で相当量 の砂碩をかなり乱雑に取り込んでいるもの(第 X-2 覀群), iii）腐植集積が卓越し異物質の供給が注とんどないもの (第 IX-2・IX-4 亚群)等を識別し得る。これら 3 様式のう ち i ）については水辺周辺の地表の表層物質にある程度の 不安定要因が，またii）については周辺地表物質のかなり活 発なマスムーブメントと湿性堆積環境でと相当の流水性が それぞれ考方れるが, iii)については前 2 者に対し相対的 に静穏な地表状態の下での安定的な湿原堆積物の形成がな されたといえる。一方上記 alluvial deposits のらら砂碩質 な子のの中には一部に流理構造がみられ, 前記の湿原性水 辺環境とは異なる流水性水辺環境が考えられる(第 XI 群, XII-1 覀群, XIII 群等)。

以上の堆積物のらち腐植に富寺 5 層準（第 V 群表層, IX-4 亜群中央・X-1 亜群下層, XI 群表層・XII-1 亜群中 央)の試料について $\mathrm{C}^{14}$ 年代測定を拈こなった(日本アイン ○一プ協会による)。最上位層準である第 V群表層で 36 , $600_{-1,500}^{+1,830}$ 年 B.P. が得られたが，これ以下の各層準では同 測定法の限界を超す 37,800 年 B.P. 以上の年代が得られて いる。

またこれらの堆積物から採取した計 48 試料についての 花粉分析の結果からは，一応 9 花粉帯を区別することがて 


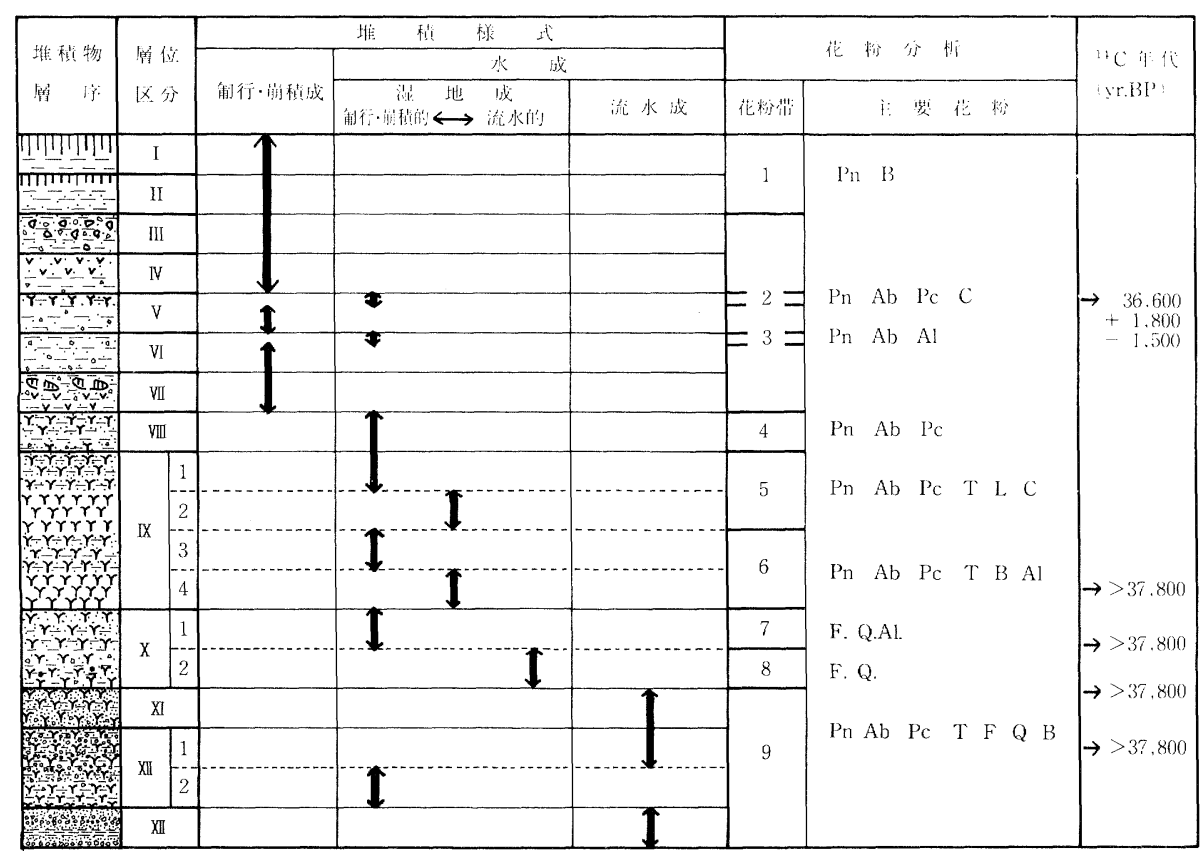

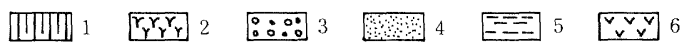

1: 表土(腐植質)， 2 : 泥炭等の腐植物， 3 : 磁， 4 : 砂， 5 : シルト・粘土， 6 : 軽石, Pn: Pinus, Ab: Abies, Pe: Picea, T: Tsuga, L: Larix, C: Cryptomeria, B: Betula, Al: Alnus, F: Fagus, Q: Quercus

きる。即ち, 第 9 帯: 堆積物下部の第XI・XII 群の層序に 当り Abies・Plcea・Tsuga が優勢, Fagus・Quercus b相当 高率で現れ, 植生带でいら山地带付近の森林相が考学られ る。第 8 带: 堆積物層序の第X-2 亜群に当り Fagus ・ Quercus が急増, Abies・Picea・Tsuga等が急減し, 少なく とも現在之同程度の気候環境が考光られる(颃々らく Würm 永期中またはそれ以前の温暖期に相当するもので あろ弓。) 第 7 帯：堆積物層の第X-1 亚群に当り, Fagus ・ Quercus がやや減じ Abies P Picea・Tsuga等が再び現れ始 め, Alnusの増減が顕著で, 気候寒冷化がうかがえる。第 6 帯: 堆積物層序の第 IX-3・IX-4 覀群に当り, Pinus ・ Abies - Picea ・ Tsuga - Betula（花粉粒径の大さい ermanii 型) ・Alnus 等が優勢, Fagus・Quercus の減少, 小型粒径の Betula (多分 nana 型であろら) の出現等が認められ, 気候 寒冷化の傾向が再に明瞭である。第 $5 \sim 3$ 帯：堆積物層序の 第 IX-2 亜群, 第 VIII 群・第 VI 群表層等に当り, Pinus • Abies・Picea・Tsuga 等が優勢，Larixが現れ (第 5 帯), Fagus・Quercus は汪之えど消滅し, 各花粉帯中で最寒冷環 境を示す。第 2 帯: 堆積物層序の第 $\mathrm{V}$ 群表層に当り, 第 5 $\sim 3$ 带に比へ Cupressaceae $\cdot$ Cryptomeria $\cdot$ Fagus $・$ Quercus 等が現れ始め Alnus 法減少し, 同様の寒冷環境下ではある がある程度の湿潤も考光られる(本带の $\mathrm{C}^{14}$ 年代として $36,600_{-1,500}^{+1,830}$ 年 B.P. が得られている)。第 1 带: 堆積物層 序の第I・II 群飞当り,Abies・Picea・Tsugaは消隇,

Pinus・Bbtula が優勢で冷涼〜冷温帯的環境の森林相とい 光る。

[蛇塚地区]堆積物の詳細な検討は今後に行ならが, 確 認できた層厚約 $5 \mathrm{~m}$ の堆積物には葉水地区の場合と同様 の層序が認められる。ただ, 葉水地区では顕著な婎積を示 していた colluvial deposits は本地区では貧弱で, 逆に本 地区の場合には alluvial deposits の形成が卓越し，特に湿 原性堆積物が影著に認められる。このことは, 本地区周辺 の地表起伏が小さく, また対象とした湿原が浅く広い谷状 緩斜面の中央低所に位置していること等から考えて, 葉水 地区に較べて本地区の場合は相対的に静穏な湿原性の堆積 環境が，かなり古い時代から継続してきたことを示すもの と考えられる。 
陸前高田平野の地形と沖積層

三陸りアス海岸中部の気仙川下流に広がる陸前高田平野 （以下，高田平野とよぶ）のボーリング資料により，沖積 層の区分を行ない，沖積世に捺ける本平野の形成過程を考 える。

高田平野の地下には 2 段の埋没段丘がみられる。それら を埋没上位面，埋没下位面とする。前者法高田平野中部の 川原川と小泉川にはさ的る部分にみられ，海抜高度は一 2.6〜 - $4.2 \mathrm{~m}$ である。これら陸上部の低位段丘のらち, 高低 の久連坪面に対比される。後者すなわち埋没下位面は気仙 川, 川原川, 浜田川沿いにみられ, 最子海寄りで $-27.3 \mathrm{~m}$ の高度示す。この面快低位段丘のうち低位の和野面に対 比さ机る。

沖積層は埋没下位面を約 $3 \mathrm{~m}$ 程度切り込んだ谷の, 高 度 $-30.2 \mathrm{~m}$ から堆積がはじまる。沖積層の最下部に相当す る下部砂層は砂が卓越するシルト質砂で, 全体に貝化石が 含末れる。これは浅海での堆積物之思われ，海面上昇に伴 ら三角州前置層炕场ると考光ら礼る。下部砂層の上面高 度は添溧-20 m で一定している。

上部砂層の上には約 $11 \mathrm{~m}$ の厚さで中部泥層がのる。こ れはンルトを主とし，貝化石を多く含む。中部泥層は海面 が急激に上昇し，三角州底置層として堆積したもので，そ の上面高度は海寄りで $-9 \mathrm{~m}$, 内陸で $-7 \mathrm{~m}$ である。中部泥 層の頂部に近い-11 12 $\mathrm{m}$ 付近に 5 40 cm の厚さで灭 白色凝灰質ンルト層がある。内陸側では $-8 \mathrm{~m}$ 末でみられ る。この凝灰質シルト層は屈折率等から, 十和田の中掫軽 石 $(\mathrm{Cu})$ とされた。

中部泥層上には貝化石を含む砂〜ンルト質砂からなる上 部砂層がのる。これ性海面上昇が沛るやかとなった時点で
三角州前置層として，浅海で堆積したものと考兄られる。 上部砂層の上面は $-2 \mathrm{~m}$ を越えることがない。

上部砂層上位には貝化石を含まず，主として秒礫層ある いは腐植質シルト層からなる沖積陸成層がのる。この下底 部はー4 $4 \mathrm{~m}$ の浅谷をなし，また, $-4 \sim-5 \mathrm{~m}$ 付近に埋没 上位面や, 基盤岩を波蝕台的な地形がみられる。海底でも一 4 - - $5 \mathrm{~m}$ 付近飞波蝕台らしい地形がみられ, これら虫同時 期の形成になると思われる。すなわちこの時期には, 浅海 底が陸化し, 気仙川, 浜田川の流路にあたる部分では浅谷 が形成され，一部で波蝕台が形成されたと考光ることがで きる。

絶対年代, 堆積物の堆積環境などが不明であることから 海面变化曲線は求められないが, 沖積層の推積開始を約 1 万年前, 凝灭質シルト層を約 5,000 年前, 埋積浅谷を約 2 , 000 年前の形成之仮定すると, 高田平野の形成に関係する 海面変化の曲線は次の上うと考学られる。

約 1 万年前, $-30.2 \mathrm{~m}$ から沖積層が堆積しはじめ, 下部 砂層堆:積時は徐々に上昇し, その後, 中部泥層堆積時恃急 激な海面上昇を示す。凝死ンル卜層は中部泥層の上部に位 置することから，高田平野がなお沖合的な環境下にあった 時に中掓軽石が降下した。いわゆる繩文海進の最高海面に はこれよりやや遅的て到達するが, 最高海面達した後, 海面岋㠼るか胝下し, 約 2,000 年前に-4 - $-6 \mathrm{~m}$ まで 下がる。この時, 河道汇相当する部分では埋積浅谷が, そ の他では一部で波蝕台が形成された。それ以後は海面は現 在の位置まで上昇するが, 浜堤の形成, 河川の堆樍により, 海面上昇に伴ら海域の侵入はなかったと考学られる。

\section{中都市に抢汗る人口構成值の地域傾向面}

$$
\text { 大友篤・磯 部邦昭 }
$$

東京, 大阪, 名古屋の 3 大都市に招汁る人口分布の地域 傾向面については, 1979 年度日本地理学会春季大会および 1980 年 IGC 都市地理部会で報告したと扔り，一次多項式 近似による場合を除いては，都市間あるいは適用範囲の差 異によって形態が異なるものの，いずれも，都市を中心と する同心円状の人口密度の距離的変化を示すことが面的比 把握された。これは, 分析の対象範囲を, 3 大都市の市街地 またはその主要部に限定した場合であるが, 今回の報告は, 市街地および郊外地帯を含んだ都市域全域を対象とし，人
口分布に加光て，人口構成に関する諸指標の都市内分布の 全域的傾向を明らかとすることを目的として，宇都宮およ び前橋・高崎の二つの中都市の地域について, 1 次 6 次の 多項式近似に上る地域的傾向面モデルを適用した結果の中 間報告である。

対象地域範囲は，前記両都市域に注潘相応する，それぞ れ $484 \mathrm{~km}^{2}$ の地域で, 基準地域メッショ別人口, 性比, 老 年人口指数, 婦人子供比率, 女子労働力率, 第 1 次産業就 業率㧍よび 1 世帯あたり平均人員のデータを用いたなおお， 
宇都宮のほか, 前橋・高崎の連担都市の地域を選んだのは, 単一の都市中心部をもつ都市地域と, 複数の都市中心部を

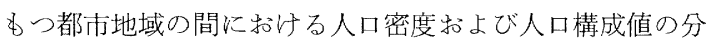
布パターンの差異を知るといら意図にもよったものであ る。

分析結果の概要は, 次のと抢りである。

（1）人口分布については, 1 次の地域傾向面の場合は, 両 都市域ともに，北東から南西にかけて人口密度が上昇する といらパターンが認められ，また， 2 次〜6 次の傾向面の場 合は，両都市域ともに，人口密度が都市中心部をピークと してそれを離れるにしたがい同心円状に低下するといらパ ターンが認められた。なお，宇都宮り場合は南北にやや長 い同心円を呈し，前橋・高崎の場合は東北から南西へか子 てかなり長い棈円形の同心円を示した。決定係数を計算す ると, 次の傾向面では, 宇都宮では $50.4 \%$ が, 前橋・高崎 については $35.8 \%$ が説明されることが知られる。

(2) 人口構成値の5ち, 性比の 6 次傾向面注宇都宮につ いては，市街地中心部で性比が低く，周辺部にいくにした がい高くなるという同心円パターンが認められたが, 前 橋・高崎については, 明瞭なパターンは検出されなかった。 しか子，決定係数をみると，宇都宮では $4.0 \%$ が，前橋・高 崎では $10.5 \%$ が説明されるにとどまることが知られた。一 方, 婦人子供比率の 6 次の地域傾向面は, 両都市域と夕に 明瞭なパターンを示さず，適合度は，宇都宫が $10.9 \%$ ，前
橋・高崎が $12.2 \%$ を説明するにすぎない。さらに，老令人 口指数の 6 次傾向面をみると, 両都市域ともに, 市街地中 心部で最も低い值を示す形の同心円状パターンが，人口密 度の場合々類似した形態でみられたが，決定係数を計算す ると, 宇都宮で $27.7 \%$, 前橋・高崎で $13.4 \%$ が説明される にすぎないことが知られる。

（3）これに詨して，女子労働力率，第 1 次産業就業率和 よび 1 世帯あたり平均人員の 6 次傾向面は, 両都市域とも, 市街地中心部で最も低く，その周辺にいくにしたがい高く なるという同心円パターン（人口密度の場合と類似した形 態の）が見出された。また，決定係数を計算すると，いず れの指標についても, 両都市域ともに，活ぼ30\%以上が説 明され，とくに第 1 次産業就業率と 1 世帯あたり平均人員 については,いずれも $40 \%$ 以上が説明されることが知られ た。

このように，市街地および効外地帯を含む都市地域の全 域を対象とした場合にお汁る人口密度と人口構成値の地域 傾向面は, 性比, 老令人口指数, 婦人子供比率といった人 口学的指標については，あまり明膫なパターンが検出され ず，しか子，適合度は小さいことが明らかになった。一方， 人口密度, 女子労働力率, 第 1 次産業就業率, 1 世帯あたり 平均人員のような社会経済的な指標については，ある程度 の適合をもつ円心円パターンが認められることが判明し た。

\section{メッシュの移動によるパターンの変動について}

\section{氷見山 幸 夫}

ある特定の種類の土地利用のような単一の事象の分析を grid map で表現する場合を想定する。ただし，便宜上，事 象の見いだされる unit cell を正の unit cell, 残りを負の unit cell とする。この正の unit cellの数が格子系（grid system) の置き方により変動寸ること, 即ち一定程度の不 確定性を有することについては, 1981 年度日本地理学会春 季学術大会で論じた。ここで快, 正の unit cellの分布のパ ターンに内在する不確定性をとりめげる。

縦方向にm, 横方向に $\mathrm{n}$ の正の unit cell からなる箱型の コロニーが，格子系が横方向に半格子変位された時にもと のパターンのままである確率を $P(\mathrm{~m}, \mathrm{n})$ とする。横方向の 半格子の変位の場合, unit cell を横に 2 等分した sub-cell のレベルの正，負の情報が与えられないこと，変位後のパ ターンを決定できない。そこで正の sub-cellの分布が random であり，その密度が $P$ であるとすると， $P(\mathrm{~m}, \mathrm{n})$ は $\mathrm{m}, \mathrm{n}$ ，および $P$ の関数になる。

$P(\mathrm{~m}, \mathrm{n})$ の一般形の導出は複雑であるから, 最も簡単な $P(2,1)$ について, その導出法を以下に示す。図は正の unit

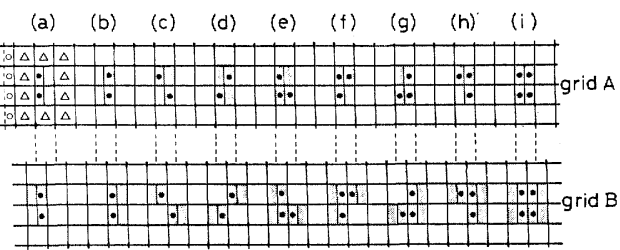

grid $B$ is displaced horizontally from grid $A$ by half a unit.

Positive unit cells and sub-cells are shown

by and $\cdot$, respectively.

Columns of Two Positive Unit Cells with Their New Patterns in the Displaced Grid System

cell が縌に 2 個並んだ状態が, 格子系を半格子横に変位し た時にどのように変化しつるかを示している。

sub-cell のレベルの正・負の組み合わせは 9 通りある が，そのおの扔のに詨応して変位後の格子系では 9 通りの 状態がある。このうち(a)の場合と (b) の場合は位置的には ずれているが，変位前と同じパターンを有する。従って， 
$P(2,1)$ は (a)〜 (i) の状態のうち, 正の sub-cell の配置が (a)か (b) である確率と一致する。即ち，(a) か(b)の扣こる確 率を(a)〜(i)のいずれかが抗こる確率で割ればよい。(a) (b) は同じ確率でおこるはずであるから,(a)についてだけ計 算する。上の計算をするにあたっては, unit cell が正の sub-cell を有しない確率 $P_{\mathbf{0}}, 1$ 個だけ有する確率 $P_{1}$, それ に2 個有する確率 $P_{2}$ をあらかじめ知って拉くのがよい。 それらは容易に $p_{0}={ }_{2} c_{0}(1-p)^{2}=(1-p)^{2}, \quad p_{1}={ }_{2} c_{1} p(1-p)$ $=2 p(1-p), p_{2}={ }_{2} c_{2} p^{2}=p^{2}$ と計算される。(a)である確率の 計算は以下のようになる。

$$
\begin{aligned}
& \left(\frac{1}{2} p_{1}\right)^{2}\left(p_{0}\right)^{10}(1-p)^{4} \\
& =(p(1-p))^{2}(1-p)^{4}\left(p_{0}\right)^{10}=p^{2}(1-p)^{6}\left(p_{0}\right)^{10}
\end{aligned}
$$

ここで $\left(\frac{1}{2} p_{1}\right)^{2}$ は 2 個の正の unit cell が正の sub-cell を左側にのみ有する確率， $(1-p)^{4}$ は，図中○印をつけた 4 個の sub-cell が負である確率, $\left(p_{0}\right)^{10}$ は $\triangle$ 印をつけた 10 個 の unit cell が負である確率である。一方(a)〜(i)のいずれ かの括こる確率は

$$
\begin{aligned}
& \left(p_{1}+p_{2}\right)^{2}\left(p_{0}\right)^{10} \\
& \quad=\left(2 p(1-p)+p^{2}\right)^{2}\left(P_{0}\right)^{10} \\
& \quad=\left(2 p-p^{2}\right)^{2}\left(p_{0}\right)^{10}
\end{aligned}
$$

である。ここで $\left(p_{0}\right)^{10}$ は(a)の場合と同じであり, $\left(p_{1}+p_{2}\right)^{2}$ は正の unit cell が 2 個ある確立である。以上の結果から

$$
P(2,1)=\frac{2 p^{2}(1-p)^{6}\left(p_{0}\right)^{10}}{\left(2 p-p^{2}\right)^{2}\left(p_{0}\right)^{10}}
$$

$$
=\frac{2(1-p)^{6}}{(2-p)^{2}}
$$

となる。

一般のmに対する $P(\mathrm{~m}, 1)$ は同様の考察から次の形であ ることが証明される。

$$
\begin{aligned}
P(m, 1) & =\frac{2 p^{m}(1-p)^{2 m+2}\left(p_{0}\right)^{2 m+6}}{(p(2-p))^{m}\left(p_{0}\right)^{2 m+6}} \\
& =\frac{2(1-p)^{2 m+2}}{(2-p)^{m}}
\end{aligned}
$$

$\mathrm{n} \neq 1$ の場合子類似の考察により計算されるが，非常に 複雑であるので, ここでは結果のみを示す。

$$
\begin{aligned}
P(m, n) & =2(1-p)^{m+2}\left(\frac{(1-p)}{(2-P)^{n}} f n\right)^{m} \\
& =\frac{2(1-p)^{2 m+2}}{(2-p)^{m n}}(f n)^{m}
\end{aligned}
$$

ここで $f_{2}=1, f_{3}=1+p-p^{2}, f_{4}=1+3 p-4 p^{2}+p^{3}, f_{5}=1-$ $6 p-9 p^{2}+3 p^{3} \cdots \cdots$ であるが, $f_{n}$ の一般形は明らかではな ᄂ.

以上のことから明らかなのは, $\mathrm{m}, \mathrm{n}$ が小さく(つまり小 さいコロニー）pが小さいならば，そのパターンの不確定 性は $50 \%$ 近くまで下がりらるが, 通常それはかなり高いと いらことである。従って, unit cell の大きさの程度のパター ンの不確定性が問題となるような精密な議論をする場合に は, grid mapの使用は不適当である。

東北地方の農村家屋に扣ける母屋平面形態の地域性

杉浦直

東北地方に打ける農村家屋形態の地理学的研究の一環と して, 本研究では，母屋平面形態 (間取り形態) の地域的 差異及び特色を検討・考察する。広域的な間取りタイプの 分布研究としては, 石原憲治 (1923) の研究があり, 東北 地方についても, 詳しく議論している。その後, 間取り形 態に関する多くの研究報告が為されているが，近年の間取 り形態の変貌を取り入れた分布論的研究は，十分ではない。 そこで, 本研究に怙いては, 現在の農村家屋の母屋平面形 態関するデータを, 東北地方内からできるだけ多く集め, その地域的差異・特色を把握するとともに，石原以降の間 取り形態の傾向の変化・動向を考察した。

主たる資料は, 石原に做い, 中学校・高等学校を通じて, 調查票を配布, 間取り平面図の作成を得て, 回収した。調 査は, 1978 80 年にかけて実施, 最終的に 41 校の協力を得 て, 約 3,000 枚ほど回収, そのらち, 明らかな非農家, サ ンプル数が極端に少ない市郡のもの, 等を除き, 本研究で は2,507 枚を使用した。その他，特に資料が不足した地域
について，役場税務課の作成した間取り図 101 枚を加光， 合計 2,608 枚，すなわち 2,608 戸の間取り図を分析した。

母屋平面形態の地域性を把握するため, 以下のような間 取りタイプの分類及び指標の選択を行なった。タイプ分類 にあたっては, 従来の研究, 特に石原憲治の分類, を参考 にしつつ，現在の形態の地域性を把握，表現でさる分類に することを基本方針とした。分類は，委ず「平入り型」と

妻入り型」に大別し, 平入り型についてのみ, 細加分 類を行なった。すなわち，農村家屋の空間は，座敷部之旧

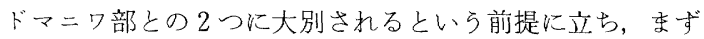
両者の結合関係から「在来型」と「中廊下型」に分類, さ らに前敷部、ドマニワ部それぞれについて細分した。座敷 部に関しては，特に石原の分類との整合性に留意し，整型 四間取, 整型多室, 喰い違い四間取, 広間型三間取, 取り まき広間型，類型取りまき広間型等を区別，さらに新しい タイプとして，廊下分断型を加えた。旧ドマニワ部に関し ては，土間の残存度によるタイブ，すなわち，全土間型， 
半土間型，一部土間型，無土間型を压別，さらに内廊，大 型突出部 (曲り), 水屋の突出, 玄関の突出等の指標を選択 Lた。

地域性の分析にあたっては，以上のタイプ分類，指標に 従って，各間取り平面図を分類し，統計単位（主として市 郡単位）を定め，各単位に扔けるそれぞれのタイプまたは 指標に属寸る家屋数の割合を算出, 分布図として表現した。 さらに，地域的特色を見るため，便宜的な地域区分を行な い, 各地域ごとに，各タイプ・指標の割合を検討, さらに 石原の研究結果と比較して，動態的に地域的特色とその動 向考考察した。

以下，結果を簡単に要約すると；

石原が調査した伝統的形態に拉いては，仙台平野とその周
辺及び福島県東部に执いて，整型四間取が主であり，その 他の地域では取りまき広間型，整型広間型が卓越していた (秋田県は整型も多かった)。現在, この地域的パターンは, ある程度残存しているが，整型四間取が，東北地方の全域 で増加し、これまで見られなかった廊下分断型，中廊下型 も, 各地に出現している。また, 旧ドマニワ部についてみ ると, 石原の時点では, 和そらく半土間乃至全土間のタイ プが主であったが，現在，無土間型がぞの地域でも半数ま たはそれ以上を占めている。内廐，曲り，水屋の突出等に ついては, 分布ハターンの残存は見られるが，数量的には かなり変化（抢そらく減少）しているものと思われる。

以上は，なだ中間的段階での発表であり，今後，さらに 多くの資料・文献を加えて，検討していきたい。

\section{旧城下町盛岡の市街地形態の変化之都心地区の形成}

梅林巌・阿部隆

本報告は「旧城下町景観」研究の一つの事例として盛岡 をとりあげ，その城下町時代の地域構造と現在の都市地域 構造とを比較検討し，一旧城下町」といら都市の歴史性が現 代の都市構造にどのように反映されているのかを明らかに しょうとするものである。ここでは盛岡の都市景観変遷過 程の記述を主とするが，東北地方の他の旧城下町との比較 や, 動態的な城下町誌を目指して Tanabe (1959) が試みた ような城下町から近代都市への地域構造の変化の模式化に ついても検討したい。

1. 藩政時代の市街地形態と地域構造

建設当初の盛岡城下にとっては, 北方の三戸との交通が 最も重要であり, 大手門が北に向けて作られたことや，当 初の中心的な町人町であった京町（本町）が城の北部に作 られたことも，北方重視の町割の結果とい光る。そしてそ の地域構造は次のような特徵を持っていた。

（1）惣構光構造…盛岡図書館蔵の正保図と呼ばれる盛岡

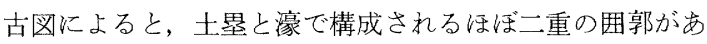
り, 城郭に近い内側の囲郭を内郭, 外側の囲郭を外郭と呼 ぶとすれば，城下の大部分は外郭の中に含李れ，いわゆる 惣構え構造を持っていた。

(2) 街区的内山下…盛岡城下の内郭之内濠の間は二, 丸・三八丸に相当し，そこに配された侍屋敷は内山下に当 るとみてよい。東北地方の他の城下町に执いても, 米沢・ 若松は二ノ丸に，仙台は三八丸纪内山下を有している。盛 岡の内山下は約 25 ha あり, 侍屋敷も 32 軒を数光（明和 3 年の盛岡城絵図による), 米沢や若松に比較しては内山下の 規模が大きい。

（3）地形々関連した地域制…盛岡城下の町割では，外郭 内部においては, 打拈よそ上田段丘上飞町人町, 館向段丘
上洔町といら地形との対応関係を認めることができる。 外郭外についてはそのような地形との対応関係は認めにく いが，寺町については河北地区では高松段丘上や上田段丘 上の屋根状の微高地に, 河南地区では段丘崖斜面にといら 対応関係が認められる。

このような建設当初の城下の地域構造と, 元文元年 (1796 年) の絵図とを比較して藩政期に扔汀る市街地形態と地域 構造の変化をみると, 河南地区に抢汁る町人町の拡大発展, 河北地区に打沙る侍町の拡大, 内山下の公用地化々いら変 化が認められる。

2. 明沿維新以後の市街地形態の変化

明治期に括ける市街地の範囲は藩政期とほほ添同じであ り，外方への拡大は汪とんど見られない。内部的には明治 期の街路網は戦後の都市計画街路を除いて基本的な街路網 は現在とあまり変っていない。橋梁についても, 明治橋・ 開運橋・夕顔瀬橋 ・ 上の橋 ・ 中の橋・下の橋はすでに架設 されていた。

大正期に入っても市街地形態に大きな変化は認められな いが, 当時の郊外地域で市営住宅の建設が行なわれ, 旧城 下の範囲を越えた市街地の拡大が始まった。

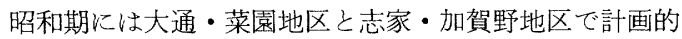
な市街化が進められ，戦前までに現在の盛岡市中心部の市 街地形態が湟活定杰った。

戦後は昭和 30 年代以降, モータリゼーションに対応して 都市計画街路計画街路の建設が進み, 昭和 44 年には盛岡バ イパスが完成した。これらの都市計画街路は城下町時代の 市街地の範囲の外側に主に建設されたが，中心部に扔いて も内丸地区が一団化の官庁街として整備され, 昭和 45 年末 でに中心部の都市計画は一応の完成をみた。 


\section{3. 都心地区の形成と移動}

現在の盛岡市の官公庁の大部分は旧内山下に立地し, 旧 内山下と官公庁地区とは明膫に一致している。このような 一致に到った要因としては, 内山下の面積が広かったこと， 官公庁 1 団地の都市計画が実施されたことなどが考学られ る。

官公厅地区の位置が変化しなかったのに対し，中心商店 街と業務地区は官公厅地区の東側の中ノ橋・看町地区か
ら, その西側の大通・中央通・菜園地区へ移動しつつある。 これは, 物的・人的交通の拠点が市街地南部の惣門付近か ら北上川右岸の盛岡駅に移動したことが大きな要因となっ ている。北上川と中津川あるいは官公广地区化した旧内山 下や城跡は昭和 30 年頃屯では駅前地区や大通・菜園の発 展を妨代，最近では，河南地区の衰退を早めていると考光 られ，盛岡の都心地区の移動をよりドラスティックなもの にしたといえる。

房総半島南部及び三浦半島南部の完新世海成段丘と地震性地殼変動

菅 沼健

南関東に分布寸る完新世の最高位海成段丘に注目し，そ の高度分布から繩文海進以降の地殼活動様式を取り扱った 報告は多い。しかし，一連の研究は年代資料飞乏しく，は たして同時期の離水なのかどうか明確ではない。

中田汪か（1980）は, 地形的証拠を重視し, 各段丘面か ら得られた ${ }^{14} \mathrm{C}$ 年代資料を基に，それぞれの形成期間を求 め，々の境界部に海水準の急激な低下を想定し，相模トラ フ沿いに発生する巨大地震の発生時期を推定した。演者は, 中田ら（1980）の方法を用いて，房総・三浦両半島の海成 段丘を形成年代的に対比するとともに，今をで除外されて いた，内湾状の低地にも注目し，広範囲に『離水現象』を 再現することにより，本地域に影響を与えた過去の巨大地 震の発生時期をより合理的に把握する。

結 論

(1) 房総半島南部では, 約 6,150 年前, 約 4,350 年前, 約 2,850 年前および 270 年前に地震性地款隆起が発生し た。

（2）三浦半島南部では，海成面は最高でも $10 \mathrm{~m}$ を越す ことはなく, 海抜 7 - $9 \mathrm{~m}$ の上位面之海拔 2 4 $\mathrm{m}$ の低位面 のみが卓越しており，その中間部は不明瞭である。

(3) 三浦半島南部の上位面仗, 約 3,000 年前に隆起し,
陸化したと考えられる。この結果, 三浦半島南部にも, + $15 \mathrm{~m}$ 付近に, 沼段丘」が存在していたとする従来の報告 は, その一部，つまり「沼段丘高度分布図」を変更しなけ ればならない。

（4）段丘面の存在とその形成年代に注目して両地域を対 比すると, 約 3,000 年前に, 南関東一円を隆起せしめた地 震性地殼隆起の発生を推定できる。しかし, この事実は, 房総半島で想定された, 約 6,150 年前, 約 4,350 年前の時 期に三浦半島では地殼変動が起こらなかったことを意味す るのではなく、むしろ, 背後に土砂供給域をもたない「お 添れ谷」の内部といら特殊な状況下にあったため, 三浦半 島は段丘の出来にくい所であったと解釈すべきである。

（5）段丘地域を含めた広い地域に認められる「離水現象」 の発生に注目して考察する。つまり, 同一地点で産出した, 潮間帯に棲息する貝化石とその直上の泥炭の年代の中間 に,「離水」を想定し，その時期を両半島で比較する。その 結果, 約 5,000 年前, 約 3,200 年前, A.D. 1923 年に両半島 に共通に離水を認めることができ，それを地震性地殼隆起 に起因するならば，この時期に「地震の頻発期をを考える ことができる。

\section{浅海砂之風成砂の粒度組成}

松 本 秀 明

海岸平野の発達過程や海水準変動を復元する上で, 平野 や砂丘地下に存在:する旧汀線の位置や高度を推定すること は重要なことである。

粒度分析に関する研究は従来多くなされており（森山, 1977 ；上杉，1971，1972など), 海浜, 砂丘, 河床など, そ れぞれ異なる㫿積営力の下での堆積物は, それぞれ違った 粒度組成をもつことが明らかとされている。
そこで, 堆積物の粒度の違いを利用して地下の旧汀線の 位置・高度を推定したいと考え，その基礎的データとして， 東北地方のいくつかの海浜に掞いて現世の砂質堆積物を風 成扣よび汀線を含さ浅海底の堆積物に分けて採取し, 粒度 分析を行なった。今回それぞれの砂質積物の粒度組成の違 いについて報告する。

試料採取地は, 仙台平野, 石巻平野, 秋田県八郎潟南部 


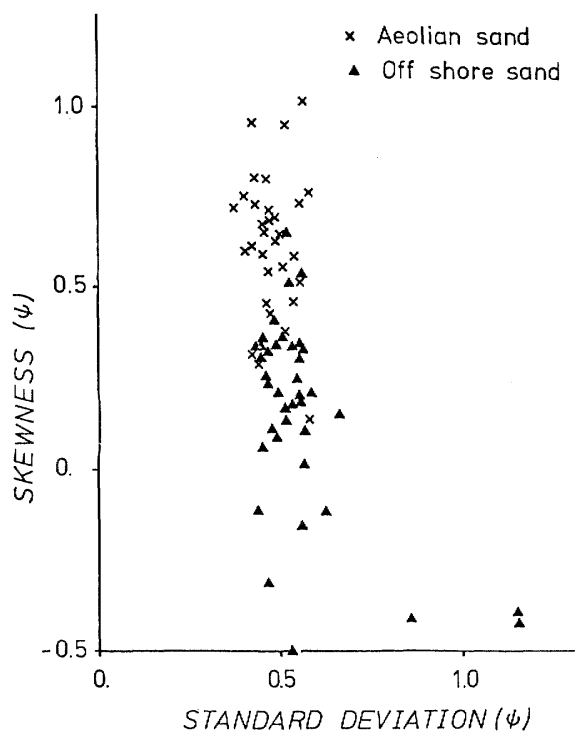

第 1 図 石巻平野の海岸に拈计万分析結果

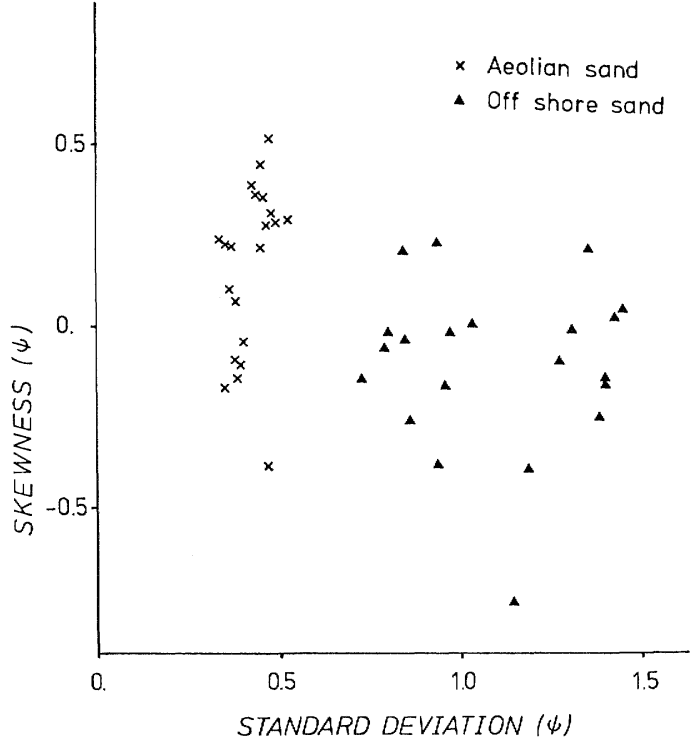

第2 図 庄内平野の海岸に扣计る分析結果
および庄内平野の海岸であり，いずれも長く連続した砂浜 海岸である。粒度分析は試料 $100 \mathrm{gr}$ を 0.5 中間隔のふるい を用いて篩分し，各試料について Friedman $(1961,1967)$ が示した積率法により skewness と standard deviation を算出した。

その結果，仙台平野の海岸に扔いてはskewnessについ て風成砂がー0.25〜+1.15 といら值をとるのに対し浅海 底の砂は土0 以下の值をとり，両者はグラフ上で明瞭に区 分される(松本, 1980)。石巻平野の海岸でも同様に skewressの值の違いにより両者は明瞭に区分でさるが，そ の境は skewness +0.4 付近であり仙台平野の場合の土0 は異なる(第 1 図)。この様に仙台平野, 石巻平野の海岸で はそれぞれ風成砂と浅海底の砂仙 skewness の值の違いに より区分することができる。一方，八郎潟南部の海岸およ び庄内平野の海岸ではskewnessの値に関しては両者の違 いは全く認められず, standard deviationの值に大きな違 いが現われた（第 2 図）。

いずれの地域に拈いても風成砂之浅海底の砂との間には 明らかな粒度の違いが認められ，堆積物の粒度分析によっ て旧汀線位置の推定が可能であるといえる。但し, 両者の 堆積物の粒度は仙台平野と石巻平野の海岸に扣いては skewness の值に違いがあり，一方八郎潟南部拈よび荘内 平野の海岸ではskewnessの值に差異はなく standard deviationの值に大きな違いがあることにより，それぞれ 区分が可能となったのである。したがって，風成砂と浅海 底の砂との粒度の違いは，それぞれ個々の地域ごとにのみ 成り立つ関係であることに注意しなければならないと考え る。

\section{カメルーン中・西部高原地帯の地形と表層物質}

田村 俊 和

1 カメルーンの西部と中部とは, 地形の大要は類似して いるが（先カンブリア系基艎岩類および一部でそれを覆う 主として第三紀の火山岩類から成る, 海抜 $900 \sim 1,500 \mathrm{~m}$ の 高原地帯), 気候的には中部 (アダマワ高原) の方がやや乾 燥し (西部では年雨量 $2,000 \mathrm{~mm}$ 程度, 乾期 (12 2 月) にも たまに降雨がある; アダマワでは年雨量 $1,500 \sim 1,800 \mathrm{~mm}$, 11 月〜2月梳とんど無降水), 土地利用・人口密度も大き く異なる（西部は汪とんど農耕地化され，人口密度 50 人/ $\mathrm{km}^{2}$ 以上, 一部で 400 人 $/ \mathrm{km}^{2}$ 以上; アダマワ南部では貧 弱な低木・草本から成る荒地の中に小さな畑が点在し，人 口密度 3 人 $/ \mathrm{km}^{2}$ 以下の地域が広く, 牛の群の通過も頻 繁)。この両地域で斜面形掞よび表層堆積物一風化断面を調 查し, 更新世後期以後の自然的・人為的環境変化と地形形 成作用との関係を考察した。

2 西部高原では, 岩質にかかわらず, 緩い凸型斜面の下 方に長大な直線状斜面の続くタイプの地形が卓越する。そ 

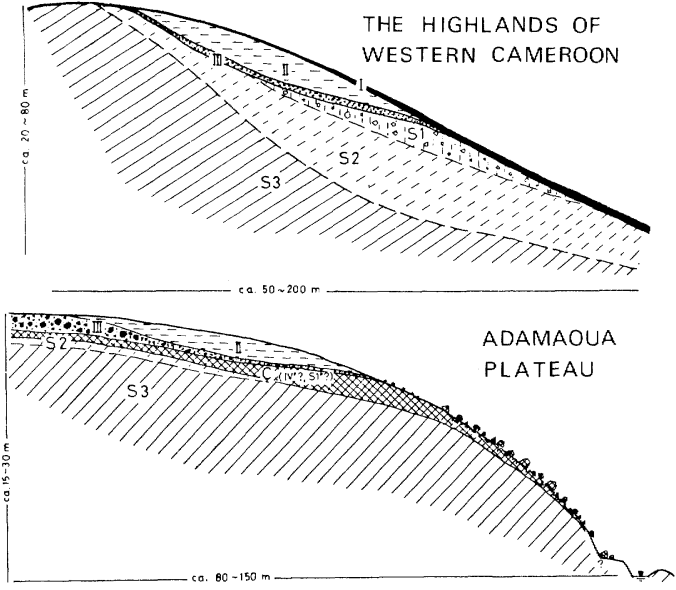

の表層を構成する土層と斜面形・斜面上の位置との関係を 模式的に示すと図（上）のようになる。一方アダマワ高原 南縁部では, キラス（鉄やアルミニウムの含水酸化物が集 積・硬化した風化皮殼）の帽岩をもつ台地状の最高位面残 片の周囲に凸型断面をもつ小丘が連なり，直線状の下部斜 面は顕著でない。その小丘の表層構成土層は, 図(下)の ように示される。

両図で, I $\left(A_{p}\right)$ ：暗褐色でわずかに腐植質のシルト質 ローム。II（コルビウム）: 赤褐色〜明褐色のらみつな粘土 質口ーム。 III (ストーン・ライン) 赤褐色一暗䶂色粘土ま じり角䃯，アダマワではキラスの破片を含む。C（キラス） 上述の硬化層, 一部には古いキラスの破片が取り込まれて 再び硬化している例がある。S1：小角碩にすこぶる富さ赤 褐色粘土質口ーム。 $\mathrm{S} 2$ ：灰一白色を基調とし，しばしば赤 みがかった雑色を呈する，基岩の原位置風化層。非硬化。

S3：風化の進んでいない基岩。

両地域を通じ，II の上面の横断面形がどちらかと言えば 凸型なのに対し,IIIが明らかに山型の横断面形を示すこと;
I が，西部高原では斜面全体に分布し，とくに中・下部の 直線状斜面でやや厚いのに対し，アダマワ高原では全く欠 如すること；アダマワではII もしばしば欠けること；逆 にCはアダマワでほぼ普遍的にみられるのに西部高原では 㭱とんぞ発達しないこと，等が注目される。

3 これらの事例から, 次のよらな地形形成作用の継起か 推定される：

1）地表面が植被をもち安定した（抢そらく相対的に湿 潤な）環境下で，基岩の深層風化が進行 ( $\mathrm{S} 1, \mathrm{~S} 2$ の形成)。 鉄の含水酸化物が表層に集積。

2）アダマワ高原では，打そらくやや乾燥したために風 化層が裸出し，酸化鉄集積層が硬化 (Cの形成)。西部では この過程は不明瞭。

3）乾燥化の進行で地表面が不安定化し，かなり急速に (おそらくwash 的作用で) III が堆積。

4）扣そらく湿潤復活に伴う比較的安定した環境下で， 斜面上部の削剝之中・下部への II の堆積が穏やかに( 打そ らくシロアリの活動にも助けられた creep 的作用で)進行。 この過程は相対的に湿潤な西部高原でより顕著。

5）西部高原では, 火入れ・耕起・踏みつけ等の影響で I が比較的速やかに移動・堆積。農耕の継続によりこの作 用は颃々らく現在も進行中。結果的にこれが侵蝕の深部へ の波及を抑えているよらにみえる。一方アダマワ高原では, より強力な火入れとその後の放置および牛による踏みつけ 等の頻繁なくり返しにより, washが頻発してII の大半を (一部ではIIIさえも) 除去。

このような作用の連鎖は扔そらく何回もくり返され，現 存のCやSのらちにはかなり以前のサイクルの産物も含ま れている可能性があるが，その最る新しいサイクルは，力 メルーン南部森林地带の類似断面から採取された石器の示 す年代，扣よびチャド湖やニジェール河口沖等で最近明ら かにされつつある古水文・気候学的事実等を考光あおる と，2）・3）が最終水期頃，4）が完新世初頭頃に相当する のではないかと思われる。

海風前線を境にした気温分布の仙台東部に扮活る観測例

石川勲

気温の日変化に関して, 海風の進入する際に気温の上昇 が緩やかになり，あるいは上昇が止まり，時には数度も低 下寸ることが報告されている。

今回, 1981 年 5 月 23 日の午後に海風前線を横断しての 気温観測をしたので報告する。

当日は日本付近が広く帯状の高気圧に覆われ，1日中晴 天で仙台気象台の最高気温は平年より $8.9^{\circ} \mathrm{C}$ 高い $29.4^{\circ} \mathrm{C}$ に 達した。宮城県沿岸の気象台関係の気象資料によると, 高
気圧下の快晴で内陸がかなりの高温であるにもかかわらず 日中の海風は石巻・塩釜で吹くのみでおり，㞿仙沼で 16 時, 志津川で 17 時から吹き始め, 19 時には南の亘理までの 沿岸全域で海からの東風が観測された。この東風に変化す る際にいずれの地点でも大きな気温の低下を伴い，志津川 では 17 時から 18 時の間に $12^{\circ} \mathrm{C}$ の低下を記録している。

この様な気象状態のもとで $1.3 \mathrm{~m}$ 高の気温を自動車を 使って移動観測した。観測路線は仙台東部海岸の深沼から 
都心に向って $240 \mathrm{~m}$ の海浜と $10 \mathrm{~km}$ のバス路線で, 主な土 地利用快海から $140 \mathrm{~m}$ の砂浜, $100 \mathrm{~m}$ の松林, $6 \mathrm{~km}$ の水 田, さらに両側は商店と住宅の混在する $1 \cdot 2$ 階建ての木造 建築の密集地である。砂浜と松林での気温はアスマン温度 計で, バス路線に沿ってはサーミスタ温度計で, 13 時 16 分 から 15 時 56 分の間に 3 回観測を行なった。

海辺から内陸に向ら気温の分布断面は次の通りである。 波打際の水温性約 $20^{\circ} \mathrm{C}$ であるがその地点での気温は $18^{\circ} \mathrm{C}$ で, $140 \mathrm{~m}$ の砂浜で $21 \sim 22^{\circ} \mathrm{C}$ に急昇温する。バス路線沿い の気温は, 13 時 16〜28 分, 14 時 14 分〜33 分の観測とも内 陸ほど高温で $27^{\circ} \mathrm{C}$ に達し，この時の昇温率は $0.86^{\circ} \mathrm{C} / \mathrm{km}$ である。しかし 14 時台の観測の際に, 海岸から 7 7.5 km の区間で内陸に向って $4^{\circ} \mathrm{C}$ の急激な昇温がみられ $31^{\circ} \mathrm{C}$ に 達した。さらに 15 時 28〜56 分の観測では, 海岸から 3.5 $\mathrm{km}$ までの昇温率は前 2 回の観測と同じで $3^{\circ} \mathrm{C}$ 上昇するが
$3.5 \sim 4.5 \mathrm{~km}$ の間で急に $7^{\circ} \mathrm{C}$ 昇温して $31^{\circ} \mathrm{C} に$ 達し, 市街地 と等温，あるいは都心より幾分高い傾向がみられた。

この気渺の急变を知る目的で，仙台市公害課の資料によ り每正時のより詳細な風向分布を調べた。朝に全域で吹き 始めた海からの東風はそれ以後西部の内陸で西風となり， 15 時李で仙台の市街地より少し東側を境に東部で法海か らの東風，西部では内陸からの西風が吹き分汁ていた。16 時になるとこの風向の不連続線は東に移動している。この 風向不連続線の位置・移動・その時刻と気温急変地点の位 置・移動扣よびその時刻がよく対応する。さらに 15 時台の 観測の際に, 気温の急変地点を境として低温な海側で東風, 高温な内陸側で西風であることを観察している。以上から 観測された気温の急変は, 低温な海からの東風と, 陸上を 吹送して来た暑い西風との境界に生じた現象と考えられ 万。

南関東の陸風開始に伴ら接地気温逆転層の変形

菊地 立

1.はじめに

従来, 接地気温逆転層に関する調査研究は, 風のない夜 が対象とされてきた。しかし，比較的風の弱い睛れた夜に 限っても, 山谷風や海陸風などに伴う風が吹く場合が多く, 終夜静穏が続くのは限られた条件の場合である。したがっ て, 接地気温逆転層は, 風の影響で静榣時の典型的な姿か ら変形されているのが常態と考えられるが, このような観 点に立つ研究は少い。そこで, 千葉県北西部を対象に, 夜 間の風の変化と気温逆転層の変形の関係を調査した。

2. 調查方法

1979 年 12 月 $3 \sim 4$ 日に千葉県環境部が実施した調査の 資料を中心何, 局地風系の变化に伴う気温逆転層の変形過 程について, 事例解析した。次に，千葉県船橋市三山にあ るNHKテレビ送信塔に括汻る観測資料と，千葉県及び東 京都の大気污染常時監視測定資料を用いて, 気温逆転層変 形の出現傾向, 逆転層変形々風の関係について, 統計的に 整理した。

3. 1979 年 12 月 $3 \sim 4$ 日の局地風系と気温接地逆転層 の変化

調査日の関東地方は, 風が弱くよく晴れていた。カイッ一 ンを用いた気温と湿度の鉛直観測，パイボールによる上層 風の観測は, 船橋市高根台, 千葉市の検見川, 稻毛海岸, 幕張海岸の 4 地点で実施された。

調査結果によれば，夜の前半については各地点とも典型 的な気温逆転層の形成過程がみられ，17 時ごろ地表付近で 気温逆転が始まり, 時間を逐って発達した。夜半には逆転 層の厚さが約 $50 \mathrm{~m}$ になり，その上空は活涪等温であった。
逆転層内は注とんど風がなかったが，その上空では弱い東 風が吹いていた。ところが, 高根台で 24 時より少し前, 検 見川と稲毛海岸では 1 時ごろ, 北ないし北北西の風が吹き 始め, それに伴って気温逆転層は大きく変形した。地表に 接していた強い逆転層の部分はほとんど等温の層となり， 50 100 m の高さに強い逆転層が上昇した。それより上空 では, 風が変る前に比べて $2 \sim 3^{\circ} \mathrm{C}$ 気温が低下したが, 気温 鉛直傾度はやはり小さかった。気温逆転層の構造は 7 時ご ろ屯で同様で，8時すぎに太陽が昇ると急速に等温になっ て解消した。一方, 平坦な草地の幕張海岸では, 逆転層の 変形が少なかった。高根台, 検見川, 稲毛海岸の 3 地点は $12 \mathrm{~km}$ 離れているが気温逆転層の変形過程はよく似てい た。気温逆転層の変形をもたらした北よりの風の起源を知 るため, 流線解析をした結果, 北ないし北西の風恃東京都 西部の山麓で 18 時前に始をり, 明瞭な前線を伴って次第に 東へ拡がり, 前記のように24 1 時に千葉県北西風に達し たことが認められた。上層風観測によれば，北西風の旼さ は約 $300 \mathrm{~m}$ で安定していた。以上のことから, 接地気温逆 転層の変形は局地現象にとどまらず，寒冷な北西風の開始 によって広範囲の地域で対応して発生する現象である。

4. 気温逆転層変形の発生傾向及び風との関係

気温逆転層の変形の発生傾向をみるため, 船橋市三山の 観測資料を用い，1975１979 年の 12 月について毎日の気 温変化を調べ, 逆転層の変化の特徵をもとに7つの型（A 〜 G型）に分類した。それによれば，上記の事例に示され た変化型 ( $\mathrm{F}$ 型) が最も多く発生し，5年間で 179 日（欠測 6 日）のらち 34 日であった。各変化型を天気別及び風別に 
みると、いずれもよい対応を示した。そのうち，F型の発 生は 1 2 例を除さ晴天で, 風が始め東よりで夜半すぎに北 よりに変化した日に限られた。

また，F型の日について気温逆転層が地表付近から上空 八転移した時刻を基準に，その前後の風をみると，変形前 は8 9 時間前から風速 4 $5 \mathrm{~m} / \mathrm{sec}$ 以下の比較的弱い東 よりの風が吹いており, 変形後は $4 \sim 7 \mathrm{~m} / \mathrm{sec}$ の風になり, 10 時間任ど持続する傾向が涩められる。同様に，船橋市三 山の逆転層変形時刻を基準として東京タワーの風向を整理 すると, 東よりの風から北よりの風への変化は共通するが, その変化が三山よりも2３時間先に生じている。この北上
りの風について広域的にみると，その出現率が東京都西部 の山麓で 17 時ごろに $70 \%$ に達し，時間とともに東へ拡 がっている。22 時ごろには東京都の東部に, 24 時ごろには 千葉県北西部でも $70 \%$ に達する。

5.あとがき

夜間の局地風により接地気温逆転層が不連続的に変形す る現象が，千葉県北西部で冬季渂い頻度で発生すること が確認された。しかし，その原因となる北西よりの寒冷な 気流の生成機構, あるいは風によって逆転層が変形する機 構の解明は今後の課題である。

\section{海岸の偏形樹に関する 2,3 の知見}

行田清 文

\section{1. 目的および方法}

発表者は, 以前, 仙台湾岸のクロマツの偏形々風のデー 夕を比較したものを発表した（1981 年春季大会）。その結 果, 海岸の偏形樹の示す風向と卓越風向とはかならずしも 一致せず，この偏形方向には，海岸線の方向が強く影響し ていることがわかっだ

以上の観点から東北地方の他のさまざまな海岸地域に拉 いて，偏形樹の分布について調査を行った。さらに，各地 域に拉いて，偏形樹の分布と風のデータとを比較し，その 偏形がどのような風を示しているかについて考察した。な 扣, 風のデータとしては，アメダスデータのうち，日最大 風速とその風向を使用した。

\section{2. 結 果}

日本海側の酒田から津軽半島にか沙ての地域では，偏形 は概标西風を示している。この偏形の示す西風は, この地 域の卓越風(ここでは, $5 \mathrm{~m} / \mathrm{s}$ 以上の頻度が年間を通して最 も高い風をいう）である。海岸ではないが，猪苗代湖岸で も，偏形と卓越風の一致が見られる。

下北半島については，西海岸では注とんどが西風を示す 偏形をして扣り，同様の傾向を示す地域は，東海岸の近く 屯で広がっている。屯た，この地域の中でも，西側に海の 広がっている地点では特に著しい偏形をしていることが注 目される。また, 北海岸と東海岸では, 同じ防風林の東側 と西側で偏形方向が異なるといら興味深い現象が見られ た。次に風との関係について調べると, 西海岸から内陸で の偏形や, 北・東海岸の防風林西側での偏形は卓越風向々 一致して扣り, 北・東海岸の防風林東側の偏形は, 6 8 月 にわずかに出現する東風に一致している。この東風を示す 偏形は，三沢付近の海岸や，いわき市の海岸においても見 ることができる。

3. まとめ

偏形方向と卓越風向との関係をまとめるために, 対象地

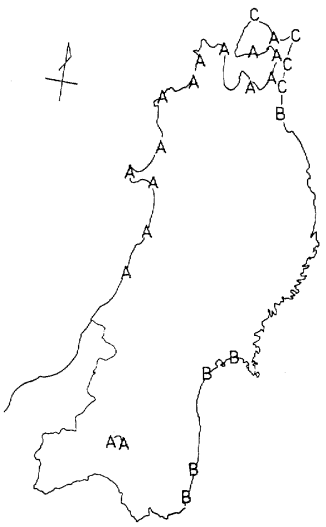

域の中であらゆるタイプを備えている下北半島付近を，模 式的に 3 種類の地域タイプに分類したのが，図（左）であ 子。

$\mathrm{A}$ ：偏形方向と卓越風向が一致するタイプ

$\mathrm{B}$ ：偏形力向が卓越風向之一致せず，稀に出現するその 他の風に一致するタイプ

C : 1つの防風林の両側で偏形方向を異にし, 一方が卓 越風向之一致し，他方がその他の風之一致するタイ プ

東北地方の諸海岸に执いて，以上の 3 つのイプの分布 状況を示したものが，図（右）である。これを見るとA夕 イプが日本海側を中心にかなり広く分布し， Bタイプは， 下北半島を除いた太平洋側に出現する。また，Cタイプに ついては，今のところ下北半島の北・東海岸に限ってみら れた。

以上のように偏形のタイブは，地域的にあるまとまりを もっているが，そこに偏形樹に対寸る海岸線の方向が強 く影響しているように考えられる。

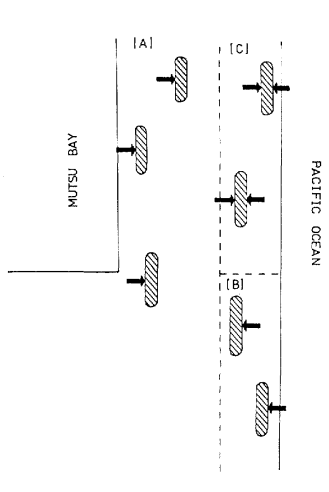




\section{弘前市から見た岩木山の雲分布}

熱帯山地にしばしば見られる雲霧帯は, 常に雲がかから て空中湿度が高く, 特殊な森林一一雲霧林が発達する。空 中湿度の植物分布に対する重要性はこれまでにも指適さ れ, 吉野 (1961) は日本の山地全体をみて, 雲のかかりや すい高度について略述している。しかし，日本の特定の山 地で雲のかかりやすい高度が述べられた例は少ない。

岩木山(海抜 1,625.2 m) 住, 他の山地から孤立した山で, 各方面から遠望され，雲のかかる高度が注ぼ一定している ように見える。そこでこの山を25ケ月にわたって観察し， 雲の分布をみた。観察は弘前市内にある弘前大学の屋上か ら行ない, 每日, 目視と写真観察を午前 8 時 30 分頃行なっ た。撮影した写真から每日の雲の分布を山体のプロファイ ル上に描き,ここから以下の結果を得た。

山体への雲のかかり方をみると, 冬季と夏季には山体全 体が雲に沶抒われることが多く，春季と秋季には山体上半
に雲がかかることが多い。山体全体が見える日は冬季に極 端に少く，この山地が日本海型の気候に支配されているこ とを示す。

雲の下限の位置は, 海抜 $1,200 \mathrm{~m}$ から $1,400 \mathrm{~m}$ にあるこ とが多く，ことに春季はこの傾向が顕著である。冬季・春 季は雲の下限の位置がやや高い。夏季は下限の位置が一定 しない。

岩木山には，山体にそった上昇気流による雲がかかる場 合は少く，広い範用を拈拈う雲の中に山体が入る場合が多 いことは，熱帯山地の典型的な雲霧帯の例とことなる。ま た，植物の生育期間である夏に雲の下限の位置が一定しな いことは,「雲霧林」の形成には不都合であろう。雲のかか りやすい高度の存在が，どのような気候景観としてあらわ れるかは, 今後の問題である。

\section{冬季北陸地方に打村る降雪分布}

設楽寛

冬季北陸地方の降雪は豪雪の多いことで知られており， 多くの事例解析の㴗か, 気候学的な研究も進められている。 これらの研究の多くは平野部特有に現われる豪雪に最大の 関心を持ち, 降水の分布型から山雪, 里雪とその中間型も しくは平均型の 3 種に分類している。しかし多数の降水分 布を具体的に取扱ってみると，如上の分類は，海岸から山 岳地域に至る狭く限られた地帯については成立つが，海岸 線の方向にこの地带の幅を拡げるにしたがって分類が難し くなってゆくよらである。つ市り，山雪型と里雪型が減少 し，代って混合型が䲡えてゆくからである。このような観 点から, 分布型を再検討しようといらのが本研究の目的で ある。

調査地域は新潟県から福井県に至る北陸の 4 県で, 調查 期間は 1969 年から 1971 年にかけての 3 年間で, 調查地域 内に降水のあった全日を対象とした。

方法としては, 北陸地方の海岸から内陸の山岳地域に至 るNW-SE方向の 15 セクションを等間隔に設け, 海岸線 から背後の脊梁部に至る区間内の相対的な位置つけを行ら ために，それらセクションの個々について等分し 5 区画を 設计た。

これら 5 区画についてセクション毎に多雪軸に相当する 降水最大值の出現頻度を求めると, 集中的に発現する区画
は，新潟県北部に扣いては山岳地に，それが県中部に扣い て平野部に移り，西部から富山県にかけて海岸部にみられ る。また石川・福井の両県に捻いては再び山岳にといらよ うに, 海岸一脊梁間において多雪軸の多発する相対位置は 地域によって異なる。

多雪軸の集中域について降水を量別にみると, 日量 30 $\mathrm{mm}$ 以下の小雪は海岸中心の分布型に多く, $40 \mathrm{~mm}$ 以上の 大雪は山地中心および平野中心の分布型に多い。

これを地域的にみると, 小雪・海岸中心の降雪型は新潟 県北部と石川・福井の両県に最も顕著に現われ, 大雪の平 野中心型の降雪型は富山・新舄の両県に現われ易く, 山岳 中心の分布型は富山以西において雪量が多い。

地域的な拡がりをみると, 海岸中心の降雪は広域的に現 われこの場合は小雪である。大雪は山岳中心あるいは平野 中心の形をとることが多いが，それぞれの地域的な拡がり は限定される。机しろ, 他の地域に执ける他の型との対応 が強い。

分布型の多様性之降水量との関係をみると, 小雪の場合 は単独分布型が広域的に現われ易く, 降雪量の増加之之も に分布型が多くなり地域的な多様性を帯びる。たとえば, 新潟・富山の両県にまたがる海岸線において, 多雪軸が海 岸に斜交して東西に走り，分布の 3 型が同時に成立する例 
は大雪時に多くこれはまた，福井・石川両県に拉ける山 岳中心の大雪に対応し易い。

以上のことから，北陸地方に扣ける降雪分布様式は次の ように要約させる。

1）狭域的にみれば，山岳に中心をもつ山雪型，平野に 多雪軸をもつ里雪型执よび海岸中心の浜雪の 3 つの型に分 類可能である。

2）このらち浜雪は広域に現われ易く，一般に小雪のこ とが多い。

3）里雪型と山雪型は地域的な搪がりが限定され易く,
視野を拡げて広域的にみると，大雪の狭域浜雪を加えて 3 型同時発現の分布パターンを形成することが少なくない。

4）その典型的な例は, 富山・新潟の両県にわたってみ られ，多雪軸が海岸に斜交して浜雪から里雪，山雪へと移 行するパターンである。しかもこれは福井・石川両県の山 雪に対応する。

要するに，山雪と里雪との分類よりはむしろそれらが地 域を異にして同時発現して形成される広域のパターンこそ 問題にすべきように考学る。今後の課題としたい。

\section{1 年度秋季学術大会巡検報告}

大会 3 日目 (10月 19 日),「地方都市盛岡の変貌」という テーマで巡検が行なわれた。

午前 9 時県庁前を出発し, 内丸の官公庁団地を通り抜け, 中ノ橋通を東へと向から。中ノ橋通には,「中三」デパート や「ェンドー」などを中心とした商業施設が集積しており， 隣接する看町地区と共に中心商店街を形成している。近年 は大通商店街の台頭や駅前地区の急激な開発により, 盛岡 に拉ける地位の相対的低下がいわれているが，河南地区の 一大中心地であることには変わりはない。

中ノ橋通から盛岡バイパスへ出て北上し, 岩山へと向か う。岩山は盛岡市東部にある小丘陵で標高 $340.5 \mathrm{~m}$ あり,ゴ ルフ場・遊園地などが設置され市民の行楽地となってい る。当日は快晴にめぐまれ, 頂上の展望台からは, 近年変 貌の著しい市街地の景観や東北縦貫自動車道, 東北新幹線 などが手に取るように見えた。さらに，盛岡市民でもあま り見ることのでさない岩手山の美しい姿が朓望できた。 次に, 旧小本街道を経て松園ニュータウンへと向から。 ニュータウンの入口にある展望台で全貌をながめた後, ニュータウン内を一巡する。松園ニュータウンは, 県住宅 供給公社によって 1969 年に計画, 翌年着工され, 1980 年に 完成した。昭和 55 年の国勢調査報告によると, 世带数 3 , 639 戸，人口 12,590 人で, 県内最大規模の二ュータウンで ある。ニーーウン内の街路は歩車道完全分離を建前とす るなど, 極めて計画的な都市づくりがなされている。また, 概して道路はかつての谷を埋めた埋土部に建設され, 一方 宅地は切土部に造成されているのが特徴的である。

松園ニュータウンから旧奥州街道を南下し, 国道 46 号線 (旧秋田街道) に出て西へ進み, 御所ダムへと向から。繫 大橋を渡って御所湖を横断し, 熬温泉を横に見ながら, 御 所ダムでバスを降りて満々と水をたたえた姿を見学する。 御所ダムは北上川総合開発により, 県内では 5 番目のダム として 1972 年に着工され，1981 年 10 月に完成した。洪水 調節, 農業灌溉, 上水道用水, 水力発電を目的とした多目 的ダムであるが，繫温泉や小岩井農場と結びついたレクリ エーション地域としても期待されている。
御所ダムからは太田地区を経由して，岩手流通センター へと向から。途中, 需石川から引水して太田から紫波にか けての水田地帯を養っている鹿妻堰を数度横切る。流通セ ンタ一は北東北の流通拠点を目指して, 県土地開発公社が 1969 年に盛岡市南郊の矢巾町・都南村の一画に造成を開 始した流通基地である。卸団地, トラックターミナル，共 同倉庫などが設立されている。ここでは，盛岡卸センタ一 の専務理事中川一郎氏からセンタ一の現状, 問題点等につ いて御説明を頂き，その後参加者との間で熱心な討議がか わされた。

昼食後, 国道 4 号線から南大橋を渡って, 旧城下町へと 入る。現在の明治橋の約 $100 \mathrm{~m}$ 下流，かつての明治橋や藩 政時代に新山舟橋がかけられていた挋前でバスを降り， 惣門跡まで歩く。新山舟橋の下手一帯は, 新山河岸と呼ば れ，北上川舟運の起点であった。ここで陸揚げされた物資 は川原町を経て惣門から郭内へ運ばれた。また, 釜石・宮 古方面からの物資は鉈屋町を通って惣門内に運ばれ, 惣門 付近一帯は藩政時代の物資交易の中心地となり, 豪商老舗 が軒をつらねていた。現在でも, 寛永年間から続く老舗で める木津屋などが昔の面影をとどめている。また，木津屋 の斜め向いにある平野商店の地下には, 藩政時代初期に北 上川が今の河道より少し北側を流れていた当時の惣門の船 着場の石組みが残っており, 郷土史家森荘已池氏の御説明 を聞きながら見学した。さらに, 段丘崖下に点在する清水 の一つである青竜清水を見学してバスに戻る。

十三日町を通り, 看町商店街を横に見ながら, 六日町, 呉服町へと入る。六日町, 吳服町はかつて藩の御用をつと める大きな商家が立ち並んでいたが, 明治以降, 吳服町は 紺屋町と共に業務街へと変わっていった。「札の辻」を経て, 紺屋町, 鍛治町, 紙町を通って上の橋を渡る。この辺一帯 は, 旧盛岡銀行, 莫莝九, 紺屋町番屋などの歴史的建造物 が数多く現存している地区である。上の橋からは, 旧閉伊 街道の起点となっていた油町を通って，再び内丸へ戻る。 途中, 藩政時代の名残りであるくい違って交差する道路を 改修している光景が見られた。 